\title{
EVALUATION OF GROUND-WATER RESOURCES FROM AVAILABLE DATA, 1992, EAST MOLOKAI VOLCANO, HAWAII
}

U.S. GEOLOGICAL SURVEY

Water-Resources Investigations Report 95-4180

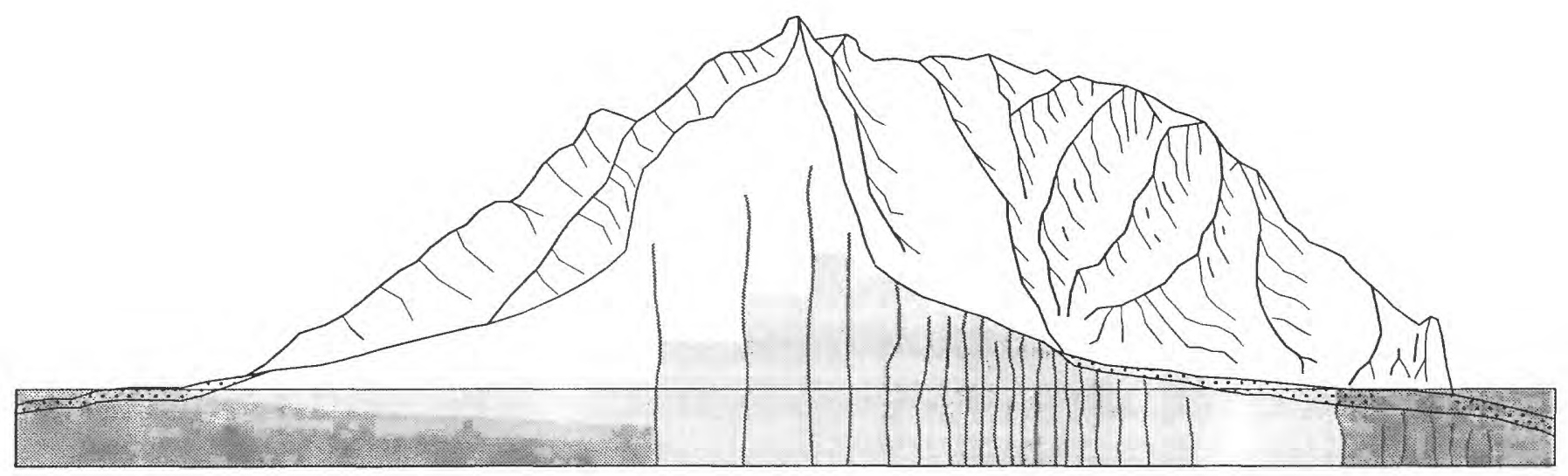

Prepared in cooperation with the STATE OF HAWAII

DEPARTMENT OF HAWAIIAN HOME LANDS and COMMISSION ON WATER RESOURCE MANAGEMENT 


\section{EVALUATION OF GROUND-WATER RESOURCES FROM}

AVAILABLE DATA, 1992, EAST MOLOKAI VOLCANO, HAWAII

By Stephen S. Anthony

U.S. GEOLOGICAL SURVEY

Water-Resources Investigations Report 95-4180

Prepared in cooperation with the

STATE OF HAWAII

DEPARTMENT OF HAWAIIAN HOME LANDS and

COMMISSION ON WATER RESOURCE MANAGEMENT 


\title{
U.S. DEPARTMENT OF THE INTERIOR BRUCE BABBITT, Secretary
}

\author{
U.S. GEOLOGICAL SURVEY
}

Gordon P. Eaton, Director

Any use of trade, product, or firm names in this publication is for descriptive purposes only and does not imply endorsement by the U.S. Government

For sale by the U.S. Geological Survey Earth Science Information Center Open-File Reports Section Box 25286, MS 517 Denver Federal Center Denver, CO 80225

For additional information write to:

District Chief

U.S. Geological Survey

677 Ala Moana Blvd., Suite 415

Honolulu, HI 96813 


\section{CONTENTS}

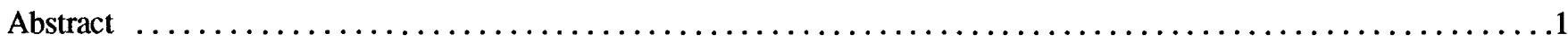

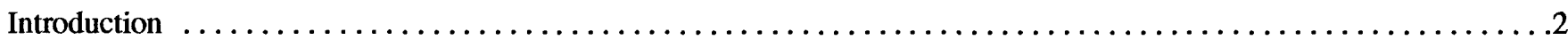

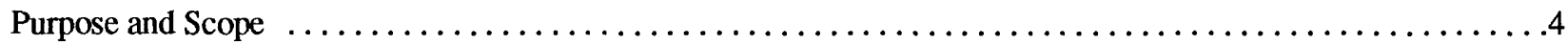

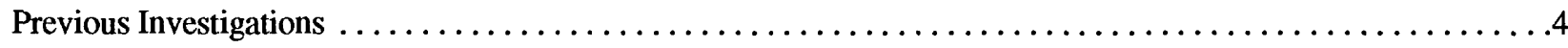

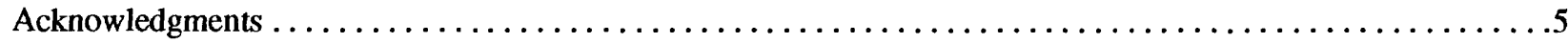

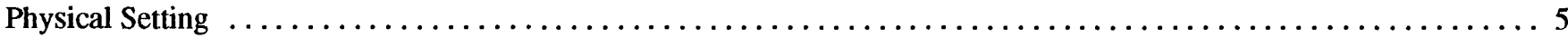

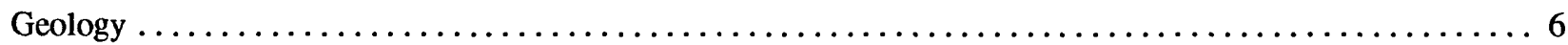

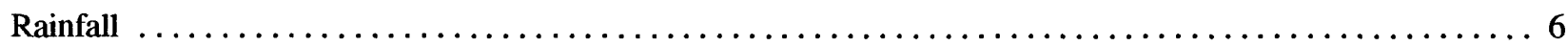

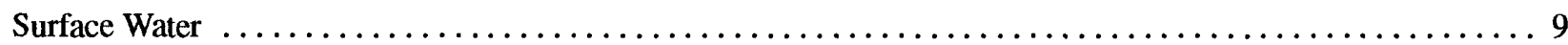

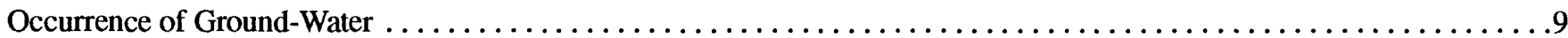

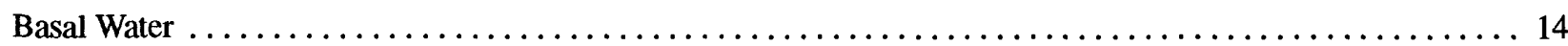

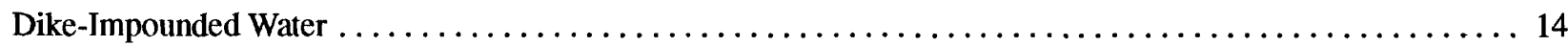

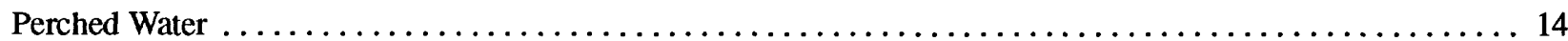

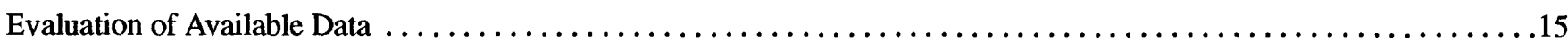

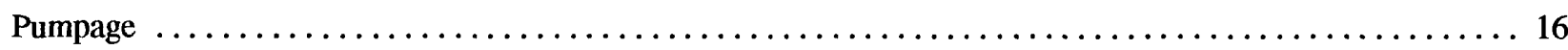

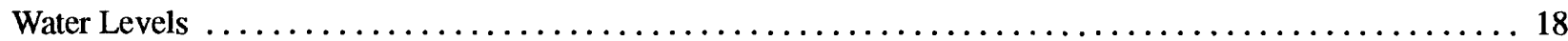

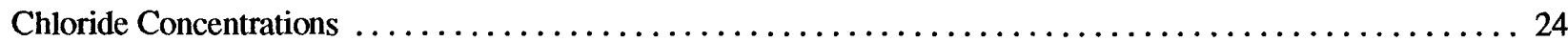

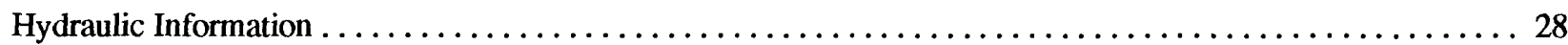

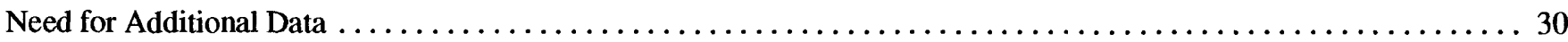

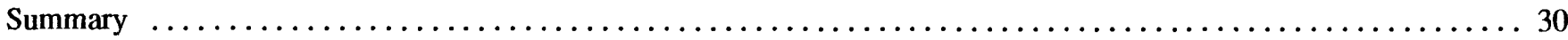

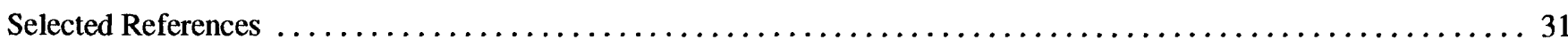

\section{FIGURES}

1-4. Maps showing:

1. Geographic areas and active stream-gaging stations, Molokai, Hawaii $\ldots \ldots \ldots \ldots \ldots \ldots \ldots \ldots \ldots . \ldots \ldots$

2. Aquifer systems, estimated sustainable yields, and descriptions of water quality, Molokai, Hawaii . . . . . . 3

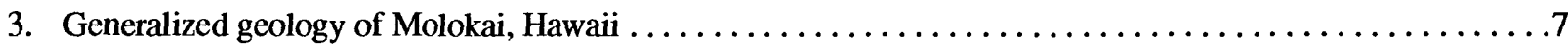

4. Median annual rainfall and locations of rain gages, Molokai, Hawaii $\ldots \ldots \ldots \ldots \ldots \ldots \ldots \ldots \ldots$

5-6. Graphs showing

5. Annual rainfall and departure from median annual rainfall at Kualapuu and Kaunakakai rain gages,

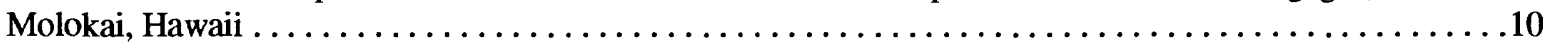

6. Median monthly rainfall at Kualapuu (for years 1900-75) and Kaunakakai (for years 1933-75) rain

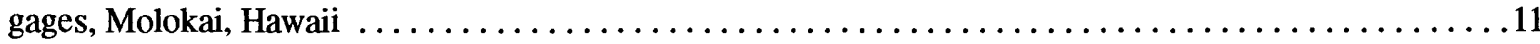

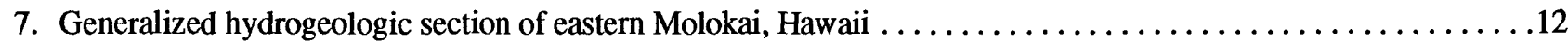

8-9. Maps showing:

8. Estimated distribution of the principal modes of ground-water occurrence, Molokai, Hawaii $\ldots \ldots \ldots \ldots 13$

9. Monthly mean pumpage from selected wells east-central Molokai, July $1991 \ldots \ldots \ldots \ldots \ldots \ldots \ldots \ldots$

10. Graphs showing monthly pumpage from selected wells, east-central Molokai, Hawaii . . . . . . . . . . . . . . 19

11. Map showing exposed dikes, and selected wells and water levels, east-central Molokai, Hawaii, $1992 \ldots \ldots \ldots .20$

12-13. Graphs showing:

12. Monthly mean water levels from selected wells, east-central Molokai, Hawaii . . . . . . . . . . . .22

13. Monthly mean chloride concentrations from selected wells, east-central Molokai, Hawaii. . . . . . . . . .25

14. Generalized section showing possible origin of brackish water overlying freshwater near Kualapuu,

Molokai, Hawaii 


\title{
Evaluation of Ground-Water Resources From Available
}

\section{Data, 1992, East Molokai Volcano, Hawaii}

\author{
By Stephen S. Anthony
}

\section{Abstract}

Available ground-water data for East Molokai Volcano consist of well-construction information and records of ground-water pumpage, water levels, and chloride concentrations. Ground-water pumpage records are available for ten wells. Seventeen long-term (10 years or more) records of water-level and/or chloride concentration are available for eleven wells; however, only seven of these records are for observation wells. None of the available data show significant long-term changes in water level or chloride concentration; however, short-term changes due to variations in the quantity of water pumped, and rainfall are evident.

Evaluation of the historical distribution and rates of ground-water pumpage, and variations in water levels and chloride concentrations is constrained by the scanty distribution of spatial and temporal data. Data show a range in water levels from greater than 850 feet above mean sea level in wells located in the windward valley of Waikolu to about 10 feet in wells located east of Kualapuu to 1 to 5 feet in the wells located along the south shore of East Molokai Volcano. An accurate contour map of water levels and chloride concentrations at the surface of the basal-water body cannot be constructed for any time period. Because water-level and chloride data are not collected at regular time intervals, many long-term records are incomplete. Information on the variation in chloride concentration with depth through the freshwater part of the basal-water body and into the zone of transition between freshwater and saltwater does not exist.

\section{INTRODUCTION}

The island of Molokai is the fifth largest of the Hawaiian islands. It is about $38 \mathrm{mi}$ long from east to west and as much as $10 \mathrm{mi}$ wide from north to south (fig. 1). About 6,600 people reside on Molokai, which consists primarily of two shield volcanoes. The older of the two volcanoes is the West Molokai Volcano, which rises to an altitude of 1,380 ft. The younger East Molokai Volcano rises to an altitude of 4,970 ft. The lavas of the East Molokai Volcano overlap the eastern flank of the West Molokai Volcano to form the Hoolehua Plain.

To assist in the management of water resources, the Water Resources Protection Plan of the Hawaii Water Plan (State of Hawaii, 1990) adopted an aquifer classification scheme and nomenclature to describe the occurrence of ground water in the Hawaiian islands. This document divides the island of Molokai into four aquifer sectors (fig. 2). The aquifer sectors are further subdivided into 16 aquifer systems each with an estimated sustainable yield. However, the divisions do not preclude the flow of ground water among aquifer sectors and systems.

Production of ground water on the island averages less than $5 \mathrm{Mgal} / \mathrm{d}$. Most of this withdrawal is from the Kualapuu aquifer system, which is located in the western part of the East Molokai Volcano (fig. 2). According to the Hawaii Water Plan, the sustainable yield of the Kualapuu aquifer system is $7 \mathrm{Mgal} / \mathrm{d}$. This value is based on scanty data and is considered to be an estimate only (State of Hawaii, 1990).

Anticipated development and related water demand in the western and central areas of Molokai led to the designation of the entire island of Molokai as a Ground Water Management Area by the State of Hawaii Commission on Water Resource Management on May 13, 1992. The water demand, based on intensive 


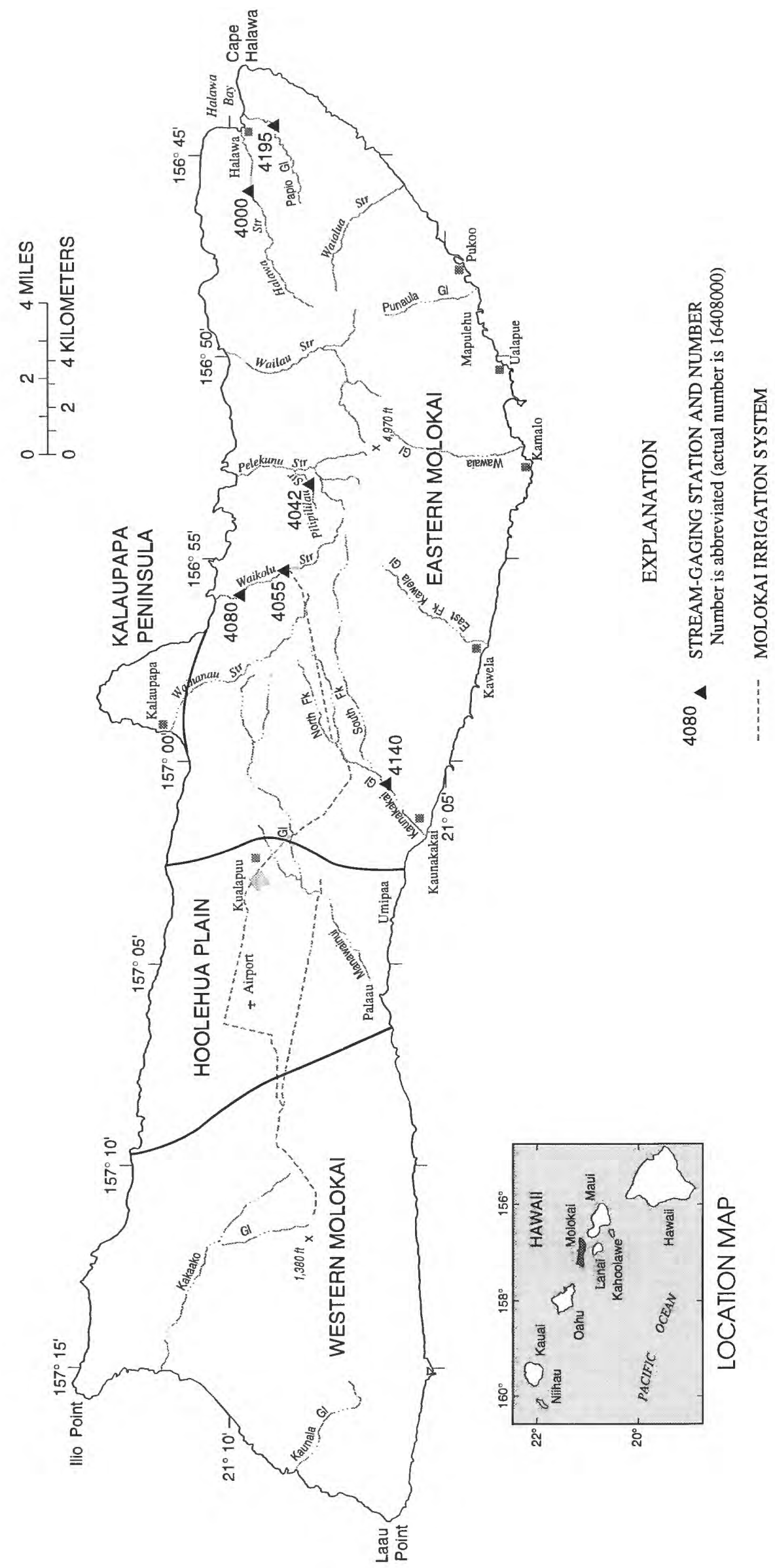

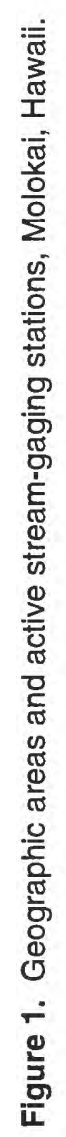




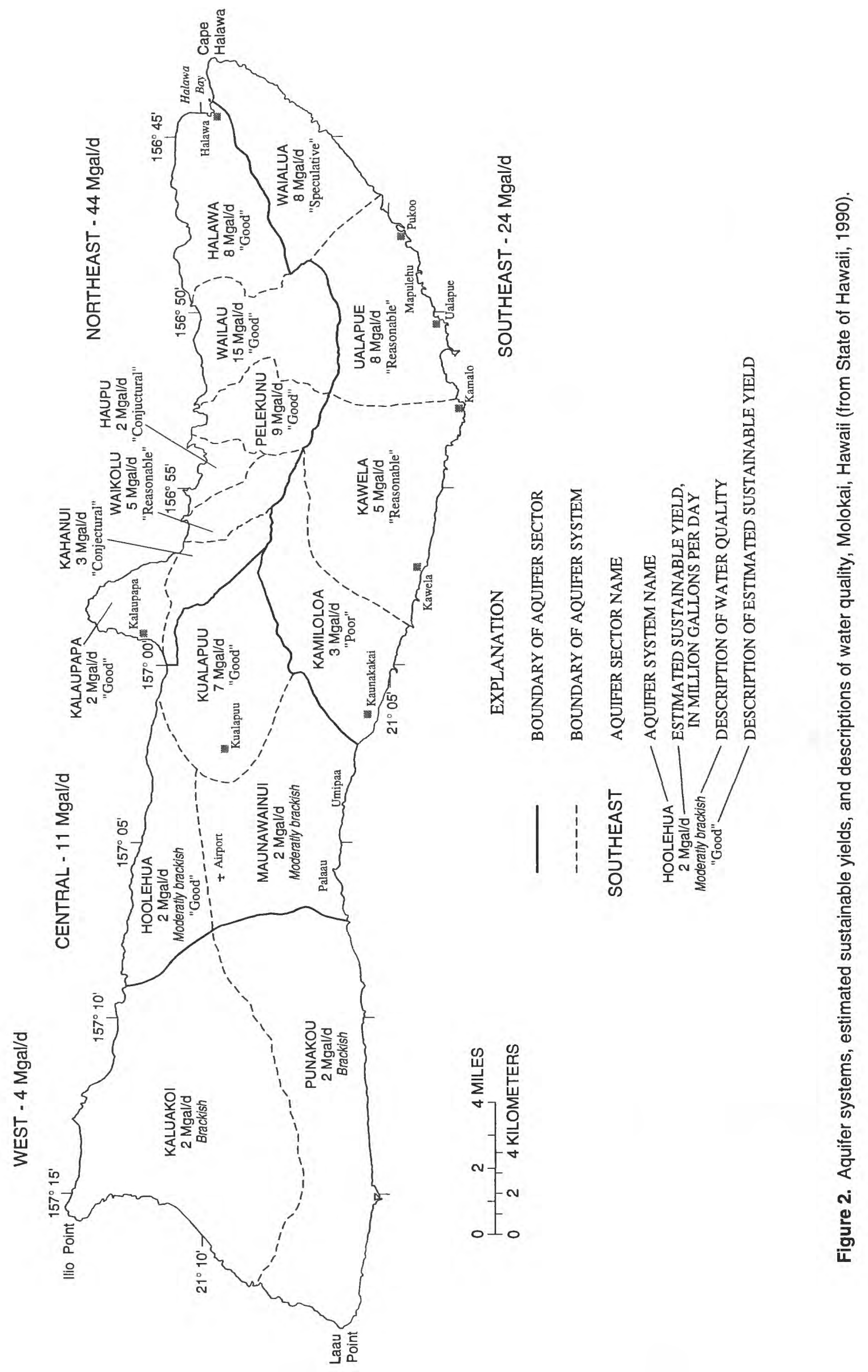


Table 1. Present and projected water use, Molokai, Hawaii

[Source of data: M \& E Pacific, Inc., 1991; Mgal/d, million gallons per day]

\begin{tabular}{|c|c|c|}
\hline Organization & $\begin{array}{c}\text { Present water use } \\
(\text { MgaVd })\end{array}$ & $\begin{array}{c}\text { Projected water use } \\
\text { (Mgal/d) }\end{array}$ \\
\hline Department of Hawaiian Home Lands & 0.38 & 27.0 \\
\hline Department of Water Supply & 0.59 & 2.5 \\
\hline Department of Agriculture (MIS) & 3.84 & 4.0 \\
\hline Kaluakoi Resort & 0.82 & 3.0 \\
\hline Molokai Ranch & 0.28 & 5.0 \\
\hline \multirow[t]{2}{*}{ Alpha U.S.A. } & 0.00 & 2.0 \\
\hline & $5.91 \ldots \ldots \ldots . . . .$. & ............ \\
\hline
\end{tabular}

agricultural production and full urban development of available land owned by public agencies and private parties, is projected to increase from about 6 to 43 Mgal/d (M \& E Pacific, Inc., 1991) (table 1). Pressure to develop the Kualapuu aquifer system to the maximum extent possible, before pursuing sources that will most likely be more expensive, has resulted in a need for a comprehensive ground-water availability study of the Kualapuu aquifer.

In April 1992, the U.S. Geological Survey, in cooperation with the State of Hawaii Department of Hawaiian Home Lands and the Commission on Water Resource Management, began a study to describe the availability of ground water in the Kualapuu aquifer. Quantification of available water in an aquifer requires knowledge of the aquifer's geometry, hydraulic properties, and the hydraulic relation between the aquifer and the area surrounding it. Knowledge of: (1) temporal and spatial changes in water levels and chloride concentration in pumping and observation wells; (2) the thickness and movement of the zone of transition between freshwater and saltwater, and (3) temporal and spatial distribution of recharge and discharge rates from the aquifer including pumpage also is required.

\section{Purpose and Scope}

The purpose of this report, prepared in cooperation with the State Department of Hawaiian Home Lands and State Commission on Water Resource Management, is to present and evaluate available ground-water data for determining the availability of ground water in the Kualapuu aquifer and adjacent areas in the western part of the East Molokai Volcano, excluding Kalaupapa (fig. 1). Because withdrawal of water from the Kualap- uu aquifer will cause ground-water levels to decline beyond the aquifer boundaries defined in the Hawaii Water Plan, the resources of the Kualapuu aquifer cannot be adequately evaluated completely without studying adjacent areas. This report, therefore, examines the available ground-water data for Kualapuu aquifer and the remainder of the East Molokai Volcano.

The evaluation of available ground-water data includes: well construction and pumping test information from existing wells, determination of the historic distribution and rates of ground-water pumpage, and an evaluation of water-level and chloride data in an attempt to determine temporal and spatial changes. The need for additional data necessary to determine the availability of ground water in the western part of the East Molokai Volcano is discussed.

\section{Previous Investigations}

The first detailed water-resources investigation of Molokai was made by Lindgren (1903) who suggested, and Howell (1938) and Austin and Steams (1954) developed plans to construct tunnels to bring water from the windward valleys on the northeast coast of Molokai to the dry leeward areas. In 1962 the Molokai Irrigation System, which develops water from streams and wells in Waikolu Valley and transfers the water through a 5.1mi development and transmission tunnel to the dry leeward areas, was completed (fig. 1). Hirashima (1963) describes aspects of ground-water storage and depletion along the tunnel. Parsons, Brinckerhoff, Hirota Assoc. (1969) describe plans to develop water from Pelekunu Valley and to develop additional water from Waikolu Valley. 
Stearns and Macdonald (1947) described the geology and ground-water resources of Molokai as part of a systematic study of the Hawaiian islands by the U.S. Geological Survey in cooperation with the former Territory of Hawaii Division of Hydrography. This report describes the geohydrologic framework of Molokai, but does not quantify the ground-water resources. G.R. MacCarthy (1941) estimated the altitude of the basal water table in the western half of the island of Molokai from electrical resistivity measurements.

Numerous published and unpublished reports describing water development plans for the island of Molokai exist. Among them are: water-supply plans prepared by the Division of Water and Land Development (1962 and 1966) for the Kaunakakai-Pukoo area and the entire island of Molokai, respectively. C.K. Wentworth (1945, unpub. letter to County of Maui on the exploration for and development of water supplies for Kaunakakai), Nance (1982), Fukunaga \& Associates Inc. (1989), and M \& E Pacific, Inc. (1991) prepared water-supply plans for the County of Maui Department of Water Supply. State of Hawaii (1990), a water-supply plan for the State Commission on Water Resource Management, provides an inventory of the water resources of Molokai, determines a sustainable yield for 16 defined aquifer systems, and recommends means of conserving and augmenting the water resources.

\section{Acknowledgments}

Interest in and support for the project by the State of Hawaii Department of Hawaiian Home Lands and Commission on Water Resource Management is gratefully acknowledged. Data provided by the State of Hawaii Department of Hawaiian Home Lands, Commission on Water Resource Management, Department of Agriculture, County of Maui Department of Water Supply, and Kukui (Molokai), Inc. facilitated the successful completion of the project.

\section{PHYSICAL SETTING}

Molokai can be geographically divided into three parts, eastern Molokai, western Molokai, and the Hoolehua Plain (fig. 1). Kaunakakai, the principal town, is centrally located mid-way along the southern coast- line. The town serves as the administrative sub-center for the State of Hawaii as well as the County of Maui. A medium-draft barge harbor is situated in Kaunakakai and the airport is located $8 \mathrm{mi}$ to the northwest on the Hoolehua Plain.

Western Molokai, which includes about 30 percent of the total land area of the island, consists of rolling hills and plateaus with a maximum altitude of $1,381 \mathrm{ft}$. Western Molokai is relatively dry owing to its low altitude and because it is shielded from trade winds by the higher altitude areas in eastern Molokai. As a result, the streams of western Molokai have cut only shallow and narrow gulches. Before 1975, about 9,000 acres near the plantation town of Mauna Loa were cultivated in pineapples. The sparsely populated western shore of the island has beautiful white sand beaches and is being developed as a tourist destination.

Eastern Molokai rises to an altitude of $4,970 \mathrm{ft}$ and covers nearly half the total land area of the island. Orographic-induced rainfall along the northern half of eastern Molokai has resulted in the formation of the amphitheater-headed valleys of Wailau, Pelekunu, and Waikolu. The slope is less dramatic on the south shore, although numerous gulches and ravines extend to the narrow coastal plain. Most of the island's population resides along the south shore of eastern Molokai. Access to the remainder of eastem Molokai is difficult.

The Hoolehua Plain is a level area between East and West Molokai with altitudes generally less than 800 $\mathrm{ft}$. Most of the plain is covered with 10 to $30 \mathrm{ft}$ of fertile lateritic soil. These fertile lands were allocated as homestead lands for native Hawaiians by the Hawaiian Homes Commission Act of 1920. Before 1985 about 3,000 acres near the plantation town of Kualapuu were cultivated in pineapples. Overgrazing by livestock and the cultivation of the land have accelerated the erosion of soil from the Hoolehua Plain (Stearns and Macdonald, 1947). The eroded soil has been transported to the south shore by surface runoff. (State of Hawaii, 1990).

Kalaupapa peninsula is a low-lying area on the north shore of Molokai. A steep, virtually perpendicular cliff separates the peninsula from the rest of Molokai, isolating two small settlements that have served as a settlement for victims of Hansen's disease since 1865. 


\section{Geology}

The island of Molokai is made up of two coalesced shield volcanoes, the West Molokai and East Molokai Volcanoes (fig. 3). There is no evidence that the West Molokai Volcano had a summit caldera as do most Hawaiian shield volcanoes, including the East Molokai Volcano. The geology of Molokai has been described in detail by Stearns and Macdonald (1947). Langenheim and Clague (1987) have updated the volcanic stratigraphy of Stearns (1946).

The West Molokai Volcano is the smaller and older of the two main shield volcanoes. It is a broad slightly dissected shield of tholeiitic basaltic lava that formed thin-bedded aa and pahoehoe flows. The flows are highly permeable and dip 2 to 10 degrees away from the principal southwest rift zone and subordinate northwest rift zone (fig. 3) (Stearns and Macdonald, 1947). Some dikes are exposed where coastal erosion has cut into the rift zones. About 16 small spatter and cinder cones are preserved on the surface of West Molokai Volcano, particularly in the northwest quadrant of the volcano. These cones constitute the alkalic postshield stage. The lavas of West Molokai Volcano are partly overlain to the east by the lavas of the East Molokai Volcano. The age of the West Molokai Volcanics is considered to be Pliocene and Pleistocene on the basis of K-Ar determinations by Naughton and others (1980).

The East Molokai Volcano is a shield volcano forming the eastern two-thirds of Molokai, and was built principally by eruptions from the summit caldera and along the east and northwest rift zones. The East Molokai Volcano overlaps the West Molokai Volcano and is overlapped below sea level by the Lanai, West Maui, and Haleakala Volcanoes (Macdonald and others, 1983). The north flank of the East Molokai Volcano has been removed by a giant landslide (Holcomb, 1985). The East Molokai Volcano is built largely of basaltic lava flows (lower member), with a thin cap of alkalic andesites and a little trachyte (upper member) (Stearns and Macdonald, 1947). The basaltic lava flows of the lower member are highly permeable compared with the dense andesite lava flows of the upper member (Stearns and Macdonald, 1947). Large cinder cones and bulbous domes are associated with the lavas of the upper member. The lavas of the lower member are cut by innumerable dikes (tabular igneous intrusions that cut across preexisting strata) lying in two major rift zones trending eastward and northwestward (fig. 3). Dikes, bulbous domes, and ash beds are poorly permeable (Stearns and Macdonald, 1947). Thin layers of ash are present locally in both members. Stream erosion has cut large amphitheater-headed valleys into the northern coast of East Molokai Volcano, exposing the dikes and the caldera complex. The East Molokai Volcanics is largely Pleistocene, but its lowermost flows are Pliocene on the basis of K-Ar age determinations on its lower and upper members (McDougall, 1964; Naughton and others, 1980).

Late in the geologic history of the island, an eruption of alkalic basalt and basanite emerged to form what is now Kalaupapa Peninsula. Kalaupapa has been proposed as a separate shield (Macdonald and others, 1983; Holcomb, 1985), but Langenheim and Clague (1987) consider it to represent a rejuvenated-stage vent associated with the East Molokai Volcano on the basis of its age and because its rocks have chemistry similar to other rejuvenated rocks in Hawaii. The Kalaupapa Volcanics has a Pleistocene age based on K-Ar determinations (Clague and others, 1982).

Deposition of marine and terrigenous sediments has built a nearly continuous coastal plain along the south shore of the Hooleehua Plain and eastern Molokai. The term caprock is used to describe the deposits of the coastal plain because the deposits tend to be less permeable than the basalts they overlie. There has been an accelerated accumulation of terrigenous sediments along the south shore in the last century (State of Hawaii, 1990). These sediments have filled in many ancient Hawaiian fishponds built around fresh or brackish springs.

\section{Rainfall}

Rainfall is highest on the crest and windward slopes of eastern Molokai and decreases rapidly toward the leeward coast (fig. 4). Rainfall on Molokai results principally from the orographic ascent of northeasterly tradewinds over eastern Molokai. The prevailing orographic rainfall pattern is interrupted by cyclonic storms from the north or by local "Kona storms" from the south and west. About 80 percent of the annual rainfall on West Molokai and the Hoolehua Plain usually occurs during cyclonic storms (Division of Water and Land Development, 1966). 


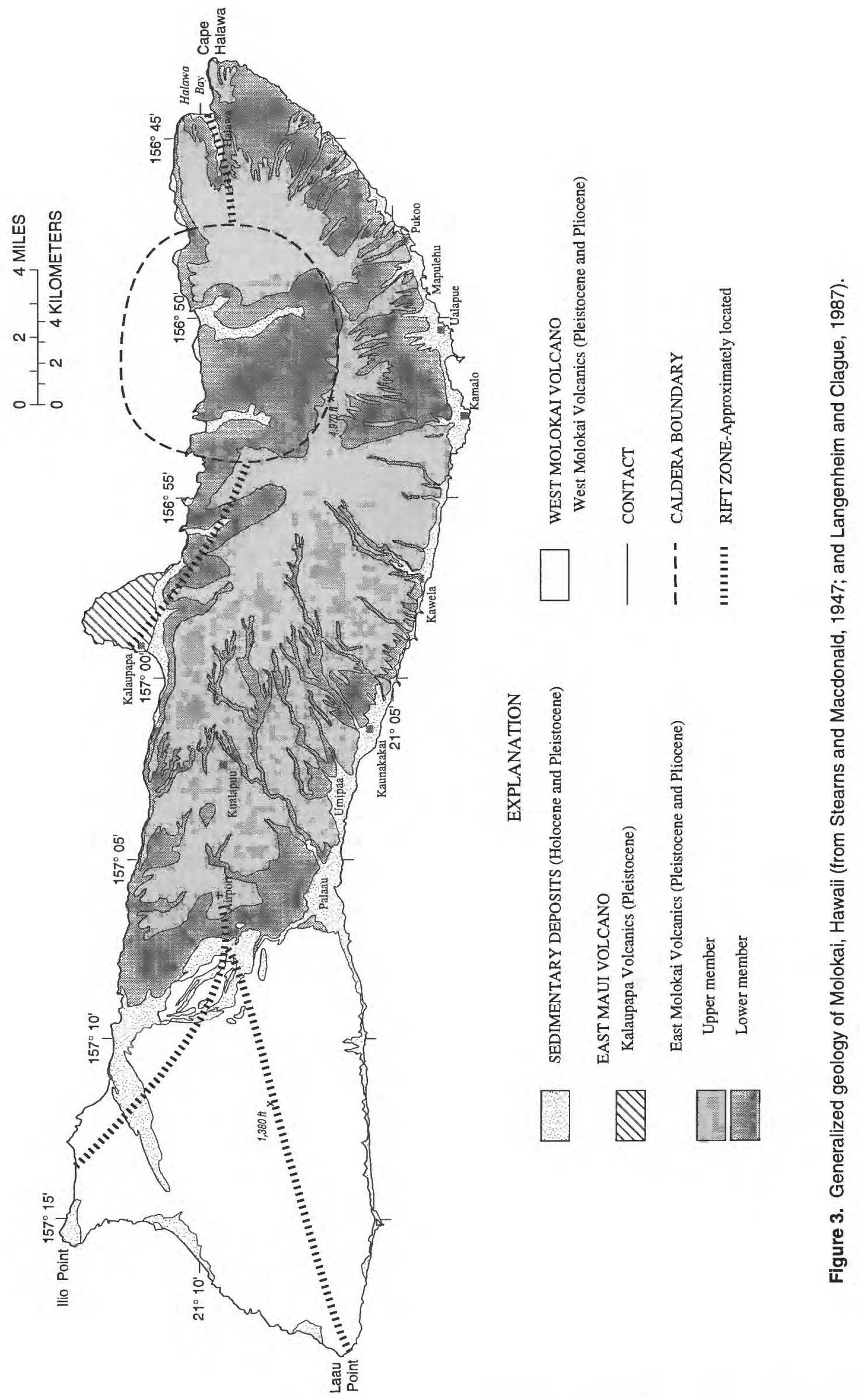




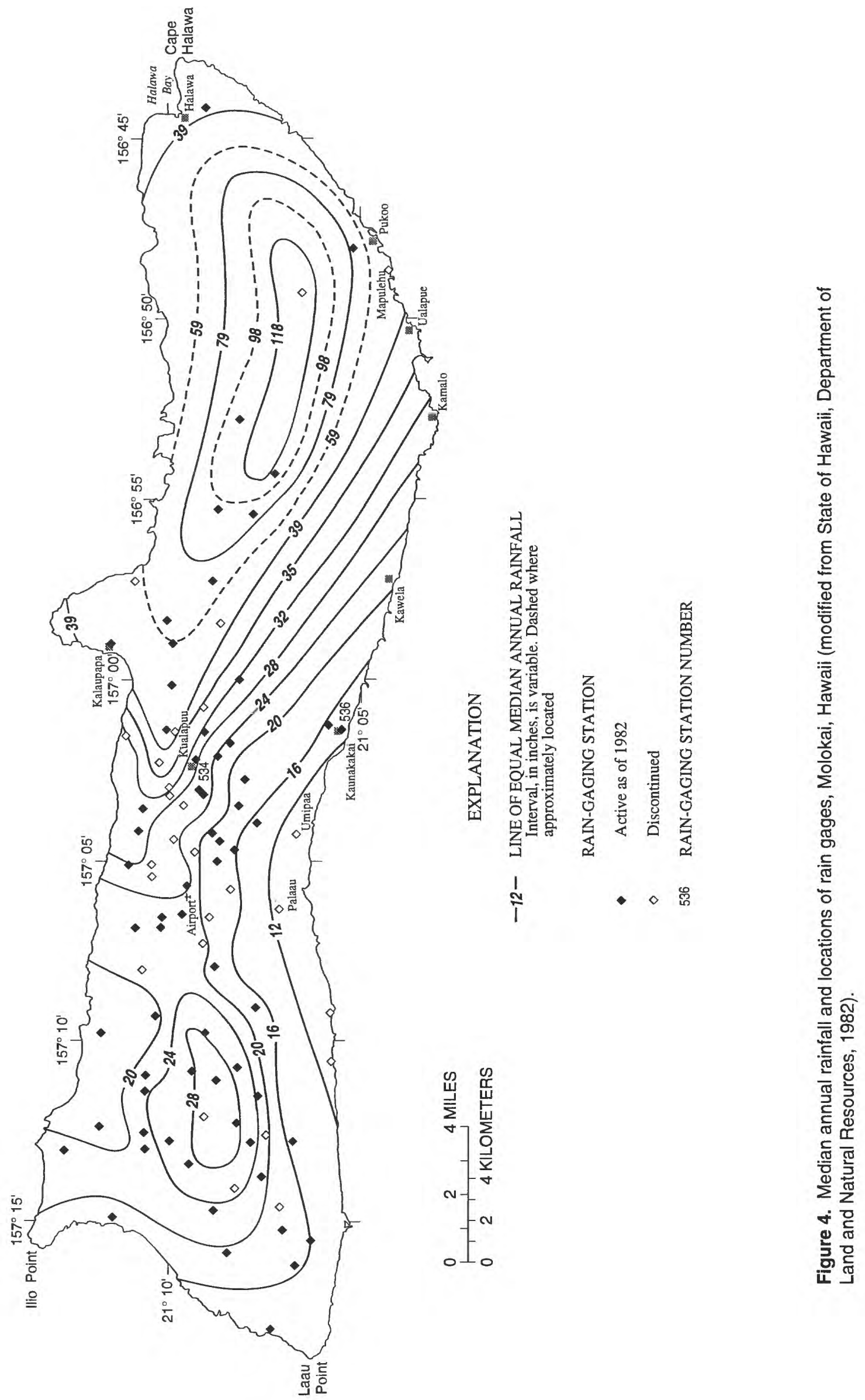


A map showing lines of equal median annual rainfall for Molokai is shown in figure 4. This map is based on data from 82 gages that were established on different dates and operated for different lengths of time. The most complete record, 76 years, was for the Kualapuu gage (gage 534). An additional twenty gages had 40 or more years of record. To eliminate the effects of secular trends, the data were adjusted to a common base period (State of Hawaii, 1982).

Median annual rainfall on eastem Molokai ranges from about 120 inches at the crest of the mountains to 12 inches at Kaunakakai (fig. 4). Rainfall on the Hoolehua Plain, which is in the rain shadow of eastern Molokai ranges between 15 and 25 inches. Although the summit of the West Molokai Volcano receives an average annual rainfall of 30 inches, much of the rest of western Molokai averages $20 \mathrm{in} / \mathrm{yr}$ or less (Giambelluca and others, 1986).

Annual rainfall at Kualapuu and Kaunakakai show that droughts lasting 3 to 8 years occur on Molokai (fig. 5). The most prolonged drought on record was during the years 1970 through 1977. The driest year on record was 1953 when recorded rainfall at Kualapuu and Kaunakakai was 39 and 23 percent of the median annual rainfall, respectively. The mean monthly rainfall at the Kualapuu and Kaunakakai gages show that the dry season usually is from May through September, and the wet season from October through April (fig. 6).

\section{Surface Water}

The only perennial streams with significant streamflow reaching the ocean are in the large amphitheater-headed valleys on the windward side of the East Molokai Volcano, from Halawa Stream on the east to Waikolu Stream on the west (fig. 1). Most of the streams along the southem and western slopes of East Molokai Volcano are perennial in their upper courses only. No measurable streamflow occurs on the relatively dry Hoolehua Plain and West Molokai Volcano. Six continuous streamflow-gaging stations are active in eastem Molokai (fig. 1) and 15 are inactive.

Streamflow data often are used in water-balance computations in which ground-water recharge is calculated from a mass balance of precipitation, evapotranspiration, and surface runoff. Surface runoff usually is estimated from a relation between rainfall and surface runoff for a limited number of basins with long-term streamflow-gaging stations. Six long-term (30 years or more) streamflow records are available for the following eastern Molokai streams: Halawa, Pelekunu, Wailau, Waikolu, Papio, and Kaunakakai.

The distribution of ground-water recharge in eastem Molokai also may be governed by geology, because the rainfall-runoff relation for basins along the southern flank of East Molokai Volcano is complicated by a permeability difference between the upper and lower members of the East Molokai Volcanics exposed at the surface. Several streams on the south flank are perennial in their upper courses where they flow over the poorly permeable andesitic lavas of the upper member. In the lower courses, however, water is lost by infiltrating into the more permeable basaltic lavas of the lower member, and evaporating before reaching the coast. The South Fork of the Kaunakakai Gulch, for example, is perennial from the head waters at $4,300 \mathrm{ft}$ to the high water fall at about 1,900 feet and intermittent below (Stearns and Macdonald, 1947). The intermittance of this and other streams in their lower courses, contrasted with their perennial upper courses, is largely the result of the streams flowing over the more permeable basalts of the lower member of the East Molokai Volcanics, after leaving the poorly permeable cap of andesitic lavas of the upper member.

\section{OCCURRENCE OF GROUND WATER}

Fresh ground water is contained in the rocks of the East Molokai Volcano. The occurrence of fresh ground water is governed by the rate of recharge from rainfall, and the hydraulic properties of the rocks. Fresh and brackish water occur in a lens-shaped ground-water body that floats on saltwater near sea level. The lens of freshwater is known as a basal-water body or GhybenHerzberg lens. Fresh ground water also can occur in compartments formed by low permeability volcanic dikes that cut across the aquifer, or as perched water. Dike-impounded and perched water occur at higher altitudes. In general, ground water flows from the dikeimpounded water bodies located near the crest of the mountains into streams, springs, and a basal-water body before discharging to sea (fig. 7). The areal distribution of basal water, dike-impounded water, and perched water was estimated by Stearns and Macdonald (1947) (fig. 8). Their estimate is based on scanty data and data collected since 1947 do not allow for refinement of that estimate. 

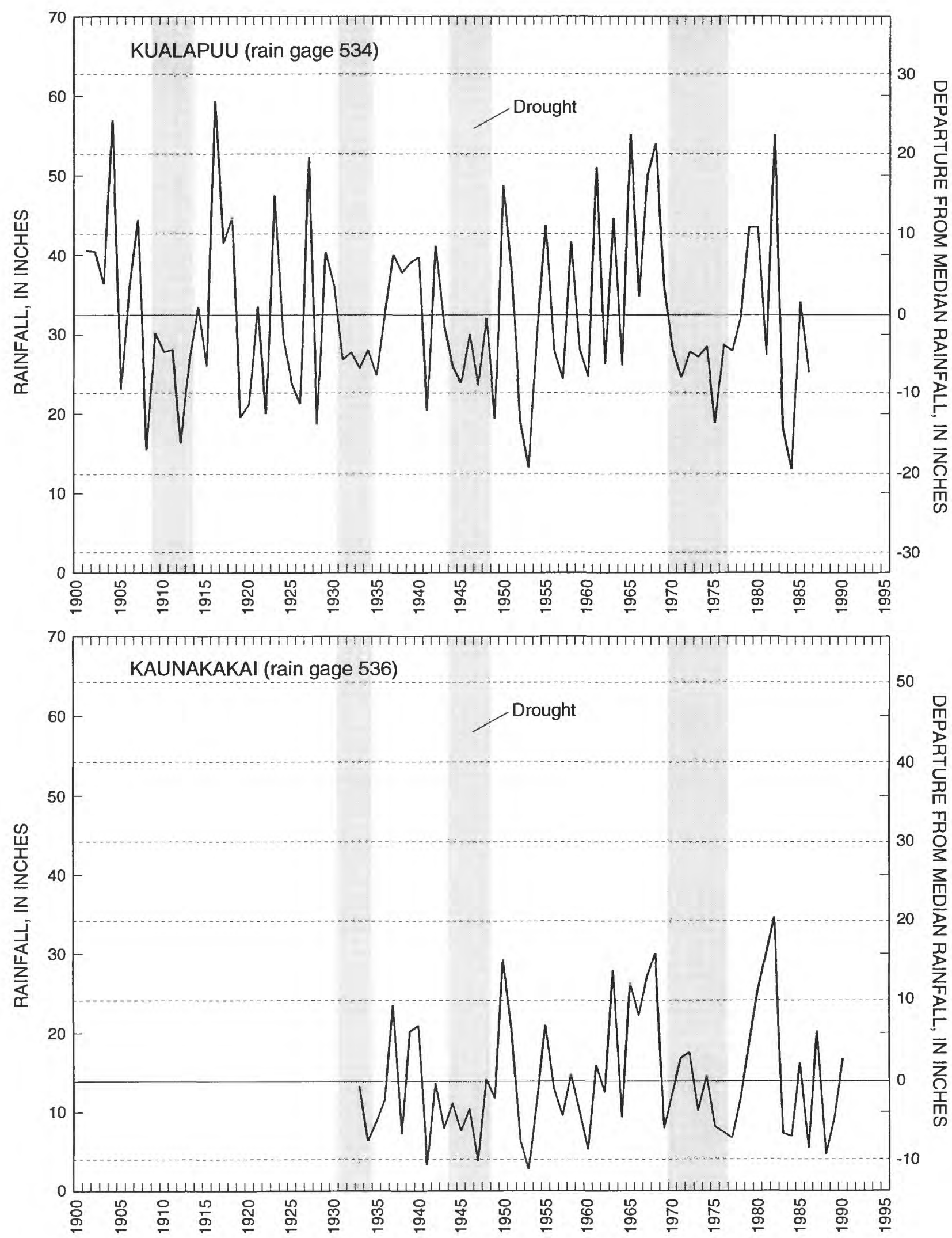

Figure 5. Annual rainfall and departure from median annual rainfall at Kualapuu and Kaunakakai rain gages, Molokai, Hawaii. 

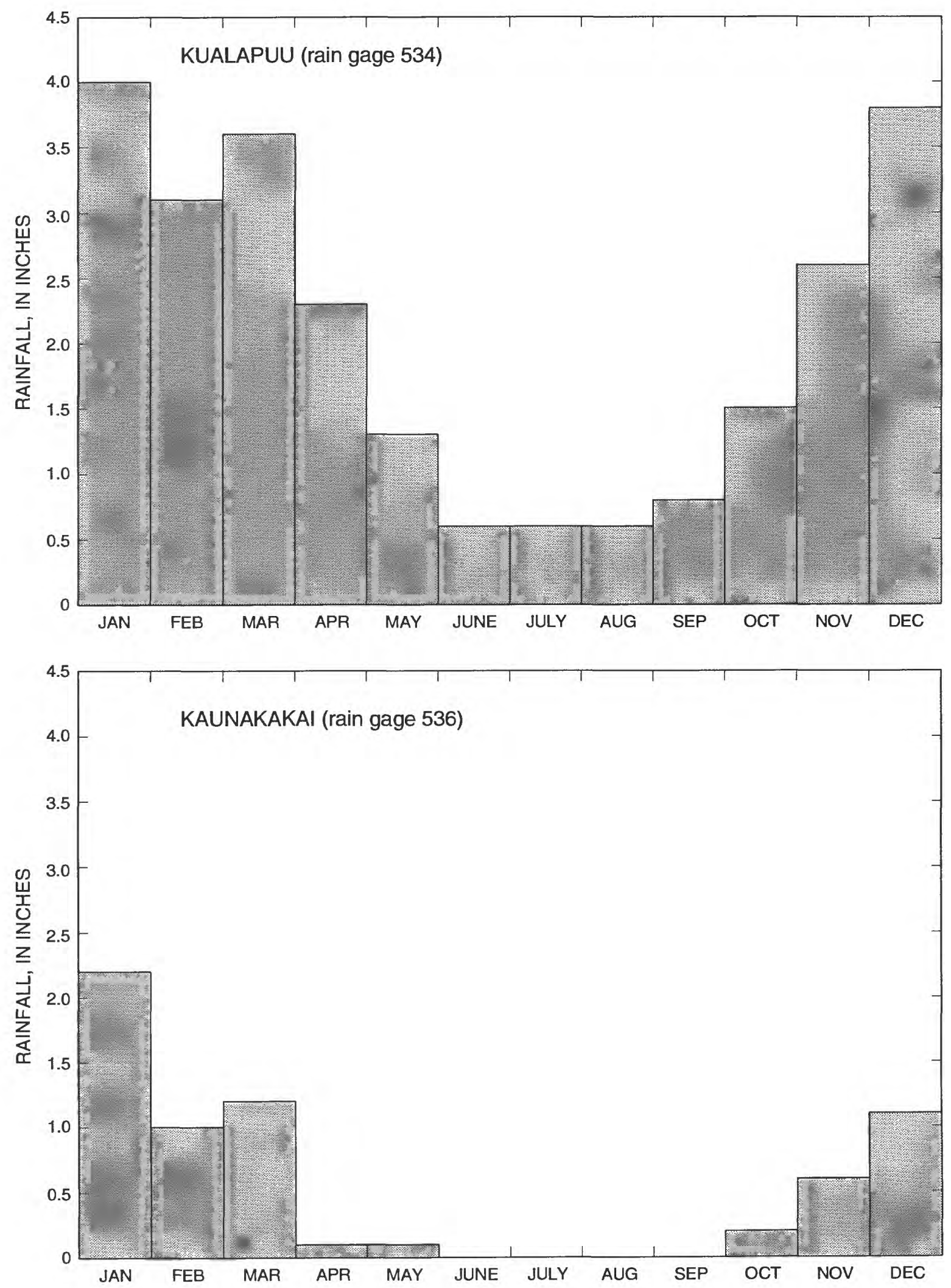

Figure 6. Median monthly rainfall at Kualapuu (for years 1900-75) and Kaunakakai (for years 1933-75) rain gages, Molokai, Hawaii. 


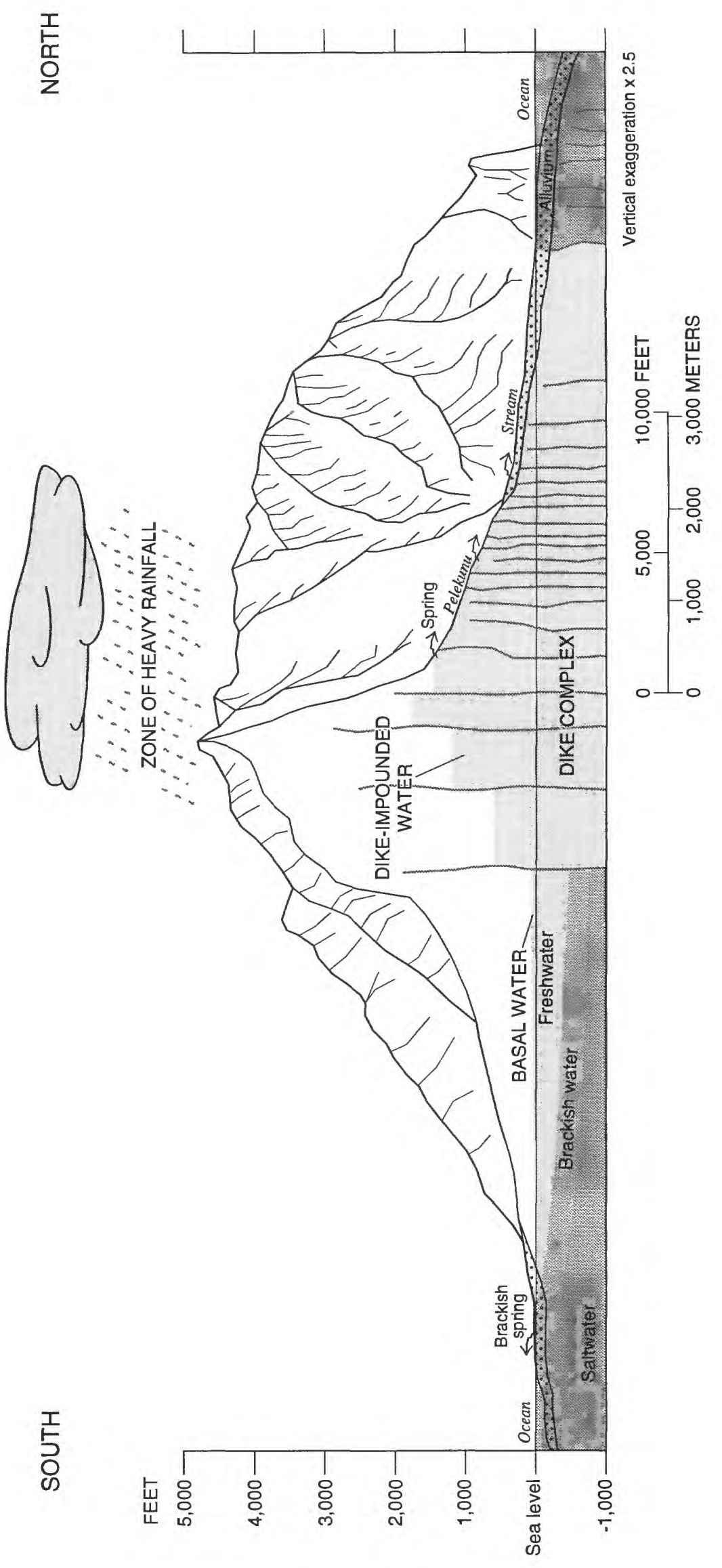

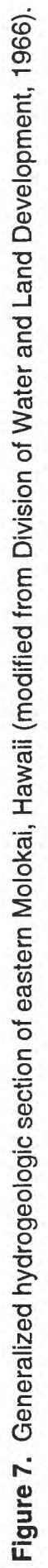



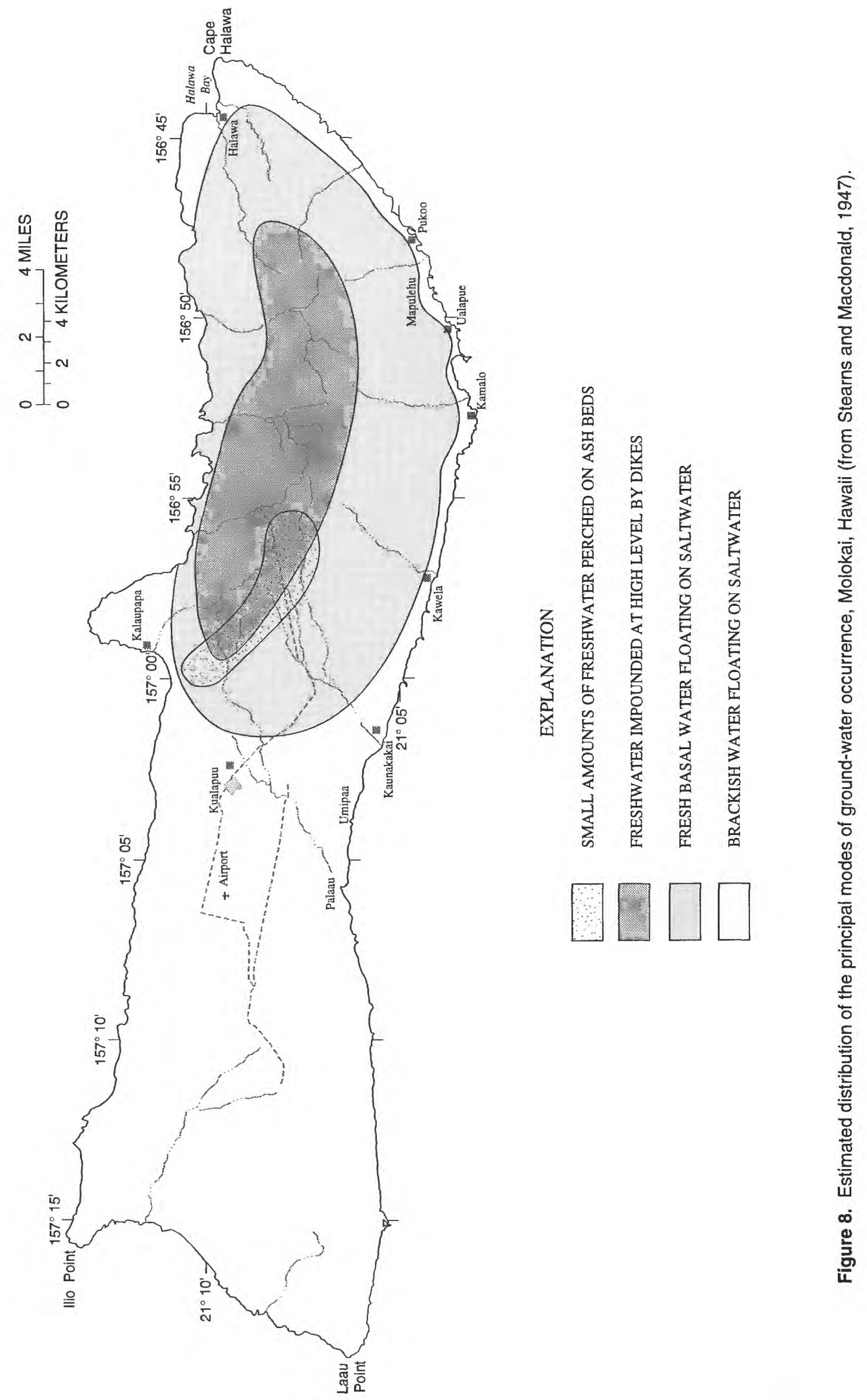


\section{Basal Water}

Basal water is the most areally extensive mode of ground-water occurrence on Molokai (fig. 8). The water table of basal ground-water bodies typically has a gentle slope toward the nearest shore and lies less than about $10 \mathrm{ft}$ above sea level. Because of density differences between freshwater and saltwater, freshwater extends to a depth below sea level of about 40 times the altitude of the water table. Freshwater grades into saltwater in a zone of transition between fresh and saltwater.

The size of a basal-water body depends on the amount of recharge received, the geometry of the system, and the permeability of the rocks in the system. The water table of basal-water bodies is typically less than $3 \mathrm{ft}$ above sea level at the shore, rising inland at about $1 \mathrm{ft} / \mathrm{mi}$ in the Pearl Harbor aquifer on the island of Oahu (Hunt and others, 1988) and about 2 to $3 \mathrm{ft} / \mathrm{mi}$ in the Hawi aquifer on the island of Hawaii (Underwood and others, 1995). Thick basal-water bodies can form where low-permeability deposits (caprock) retard the discharge of ground water at the coast. The retardation of ground-water discharge causes artesian conditions beneath the caprock and impounds unconfined basal water inland of the caprock. As a result, the water table is a few feet higher than it would be if the caprock were absent. Thick basal-water bodies also can form from other combinations of recharge, aquifer geometry, and aquifer hydraulic characteristics.

Recharge to the basal-water body contained in the rocks of the East Molokai Volcano occurs by direct infiltration of rainwater and discharge from upgradient dike-impounded water bodies. Flow through the joints and gaps in the dikes may help to smooth the effects of rainfall variations on a downgradient basal-water body by providing a near-constant source of recharge.

Dug wells, drilled wells, and Maui-type wells (inclined shaft to an infiltration gallery) are used to develop basal water on Molokai. Many shallow wells have been dug along the south shore of eastern Molokai. Most of these wells develop water from sedimentary rocks, but some penetrate the underlying volcanic rocks. Maui-type wells are shafts dug to, or slightly below sea level, with one or more tunnels extending outward 100 to $200 \mathrm{ft}$ to skim fresh water from the surface of the basal-water body. The four most successful drilled wells are located east of Kualapuu at an altitude of about $1,000 \mathrm{ft}$. These wells withdraw basal water that has a head of about $10 \mathrm{ft}$ above mean sea level.

\section{Dike-Impounded Water}

The nearly vertical volcanic dikes in the rift zones of Hawaiian volcanoes retard the horizontal movement of ground water resulting in water levels significantly above sea level. Rainwater infiltrates into the lavas between the dikes and continues to accumulate until the leakage through the dikes equals the amount of infiltrating rainwater. Dike-impounded water is probably not floating on saltwater as does basal water, but is simply held up by relatively impermeable intrusive rock beneath (Takasaki and Mink, 1985). Dike-impounded water recharges downgradient basal-water bodies through joints and gaps in the dikes and where impounded water overtops dikes (Takasaki and Mink, 1985).

Dike-impounded water has been developed mainly by horizontal and inclined tunnels. When a dike-impounded water body is first developed, initial flows are very high in response to rapid depletion of the water stored. The water level in the dike-impounded water body will lower until a new equilibrium flow between recharge and discharge is achieved.

Wailau, Pelekunu, and Waikolu Valleys cut deeply into the rift zone of the East Molokai Volcano. The springs and gaining streams in these valleys are examples of ground water discharging from dike-impounded water bodies. The Molokai Irrigation System develops water from streams and wells in Waikolu Valley and transfers the water through a 5.1-mi development and transmission tunnel to the dry leeward areas of the Hoolehua Plain and West Molokai. Ground-water sources include three drilled wells, one inside the tunnel and the others outside the east portal in Waikolu Valley, and water naturally intercepted by the transmission tunnel itself. Data collected during and after the construction of the Molokai Irrigation Tunnel indicate that about $500 \mathrm{Mgal}$ of dike-impounded water was depleted before a new equilibrium flow of about $2 \mathrm{Mgal} / \mathrm{d}$ was reached (Hirashima, 1963).

\section{Perched Water}

Water infiltrating downward through the permeable lavas of Hawaiian volcanoes may encounter lesspermeable layers and be temporarily perched by them. Perched-water bodies are separated from the basal-water body by a relatively impermeable layer and by an 
unsaturated zone above the basal-water body. These less permeable layers may be denser lava beds, or soil, but most are layers of ash up to $2 \mathrm{ft}$ in thickness. In the high rainfall areas of eastern Molokai and where the permeability of the ash layers is insufficient to allow all of the water reaching the ash beds to pass through, some of the water runs off along the top of the bed in the direction of the steepest slope. Several tunnels yield between 20,000 and $30,000 \mathrm{gal} / \mathrm{d}$ of water perched on thin beds of ash found in the andesites of the upper member of the East Molokai Volcanics (Steams and Macdonald, 1947). Most of these tunnels are at an altitude of 1,000 to $2,800 \mathrm{ft}$.

\section{EVALUATION OF AVAILABLE DATA}

Information from an inventory of existing wells provides a basis for a preliminary assessment of the ground-water resource in eastern Molokai. Well-construction, water-level, chloride concentration, and pumping-test information are available in the State Department of Land and Natural Resources, Division of Water and Land Development's (1991) "Ground Water Index and Summary" (1991, unpub.). The historical information on the distribution and rates of ground-water pumpage, water-level data, chloride-concentration data, and pumping-test results of test holes, dug wells, Mauitype wells, and drill wells were collected from well owners and from files at the State Commission on Water Resource Management and the U.S. Geological Survey. The number of wells with data are limited, with only 14 of the 120 registered wells on the island of Molokai having long-term (10 years or more) records of ground-water pumpage, water-level, or chloride data (table 2).

Well numbers in this report follow the local wellnumbering convention for the State of Hawaii (Division of Water and Land Development, 1991). The well numbers contain seven digits based on a latitude-longitude one-minute grid system. The well numbers, for example

Table 2. Selected wells and available period of record of ground-water pumpage, water-level, and chlorideconcentration data from wells in Waikolu Valley, Kualapuu area, and along the south shore of eastern Molokai, Hawaii, 1992

[*, observation well; --, no data]

\begin{tabular}{|c|c|c|c|c|c|c|}
\hline \multirow[b]{2}{*}{ Well } & \multicolumn{2}{|c|}{ Pumpage } & \multicolumn{2}{|c|}{ Water level } & \multicolumn{2}{|c|}{ Chloride concentration } \\
\hline & $\begin{array}{l}\text { Period of } \\
\text { record }\end{array}$ & $\begin{array}{c}\text { Number } \\
\text { of } \\
\text { years }\end{array}$ & $\begin{array}{l}\text { Period of } \\
\text { record }\end{array}$ & $\begin{array}{c}\text { Number } \\
\text { of } \\
\text { years }\end{array}$ & $\begin{array}{l}\text { Period of } \\
\text { record }\end{array}$ & $\begin{array}{c}\text { Number } \\
\text { of } \\
\text { years }\end{array}$ \\
\hline \multicolumn{7}{|c|}{ Waikolu Valley } \\
\hline $0855-01$ & 1961-present & 31 & -- & & -- & \\
\hline $0855-02$ & 1961-present & 31 & -- & & -- & \\
\hline $0855-03$ & 1961-present & 31 & -- & & -- & \\
\hline \multicolumn{7}{|c|}{ Kualapuu area } \\
\hline $0700-01^{*}$ & -- & & 1972-present & 20 & 1976-present & 16 \\
\hline $0801-01$ & 1961-present & 31 & - & & 1953-present & 39 \\
\hline 0801-02 & 1981-present & 11 & -- & & 1979-present & 13 \\
\hline 0801-03 & 1991-present & 1 & -- & & 1991-present & 1 \\
\hline 0901-01 & 1952-present & 40 & $1952-76$ & 24 & 1952-present & 40 \\
\hline 0902-01 & $1950-63$ & 13 & $1953-61$ & 8 & $1951-61$ & 10 \\
\hline 0905-01* & -- & & $1938-46$ & 8 & $1938-49$ & 11 \\
\hline \multicolumn{7}{|c|}{ South shore of eastern Molokai } \\
\hline $0448-02^{*}$ & $\overline{--}$ & & 1970-present & 22 & $1970-71$ & 1 \\
\hline 0449-01 & 1979-present & 13 & 1947-present & 45 & 1948-present & 46 \\
\hline $0457-01$ & 1979-present & 13 & 1974-present & 18 & 1948-present & 46 \\
\hline $0501-04 *$ & -- & & $1938-45$ & 7 & -- & \\
\hline $0501-05$ & -- & & $1947-54$ & 7 & -- & \\
\hline $0601-01 *$ & -- & & 1954-present & 38 & 1954-present & 38 \\
\hline $0603-01 *$ & -- & & $1967-77$ & 10 & $1967-77$ & 10 \\
\hline
\end{tabular}


that of Kawela Maui-type well, 4-0457-01, consist of three parts separated by dashes. The first number is the island code; "4" identifies Molokai. The island code, common to all wells discussed, is dropped in this report. The second four-digit number identifies the well location by latitude and longitude. The first two digits represents minutes of latitude and the second two digits represent minutes of longitude. The third two-digit number was assigned sequentially within a one minute grid from the oldest well to the newest.

\section{Pumpage}

Estimated production of ground water on the island averaged less than $5 \mathrm{Mgal} / \mathrm{d}$ during July 1991. Most of the basal water is withdrawn from four deep drilled wells located at an altitude of about $1,000 \mathrm{ft}$ in an area east of Kualapuu, and from two Maui-type wells at an altitude of less than $40 \mathrm{ft}$ along the south shore of eastern Molokai (fig. 9). Dike-impounded water is withdrawn from three drilled wells in Waikolu Valley (fig. 9).

Combined pumpage from the four production wells in the Kualapuu aquifer system averaged 2.7
Mgal/d in July 1991 (table 3). The combined 24-hour pumping capacity of the four production wells is 4.99 $\mathrm{Mgal} / \mathrm{d}$ (table 3) or 71 percent of the estimated sustainable yield ( $7 \mathrm{Mgal} / \mathrm{d}$ ) for the Kualapuu aquifer system defined in the Hawaii Water Plan (State of Hawaii, 1990). Ground-water withdrawals began in the 1950's from wells 0902-01, 0801-01, and 0901-01. Wells 0801-02 and 0801-03 were put into service in 1981 and 1991, respectively.

Historical records of the monthly pumpage from wells near Kualapuu are shown in figure 10. Wells 0902-01 and 0901-01 were used to irrigate pineapple fields near Kualapuu until the mid 1960's. Well 0902-01 was abandoned when less-expensive surface water from the Molokai Irrigation System became available in 1964. Pumpage from well 0901-01 was significantly reduced in 1966, but since 1976, water from well 0901-01 has been used for domestic and irrigation purposes at a resort on the west end of the island. Combined pumpage from well 0801-01 and well 0801-02 has remained relatively uniform during the period of record; however, the wet-season pumpage has recently increased. Pumpage from well 0801-03 began in July 1991 and has averaged $0.53 \mathrm{Mgal} / \mathrm{d}$ during the period of record.

Table 3. Pumping rates and capacities and July 1991 pumpage of wells in Waikolu Valley, Kualapuu area, and along the south shore of eastem Molokai, Hawaii [Mgal/d, million gallons per day; --, no data]

\begin{tabular}{|c|c|c|c|}
\hline Well & $\begin{array}{l}\text { Pumping rate (gallons per } \\
\text { minute) }\end{array}$ & $\begin{array}{l}\text { 24-hour pumping capacity } \\
\text { (Mgal/d) }\end{array}$ & $\begin{array}{l}\text { July } 1991 \text { mean pumpage } \\
\text { (Mgal/d) }\end{array}$ \\
\hline \multicolumn{4}{|c|}{ Waikolu Valley } \\
\hline $0855-01$ & ${ }^{a} 1,000$ & 1.44 & ${ }^{b} 0.48$ \\
\hline 0855-02 & ${ }^{\mathrm{a}} 1,000$ & 1.44 & $b_{0.48}$ \\
\hline 0855-03 & ${ }^{a} 1,000$ & 1.44 & $\mathrm{~b}_{0.48}$ \\
\hline \multicolumn{4}{|c|}{ 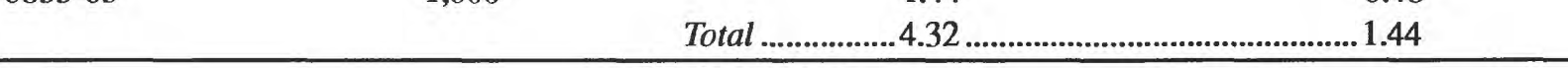 } \\
\hline \multicolumn{4}{|c|}{ Kualapuu area } \\
\hline $0801-01$ & 380 & 0.55 & 0.18 \\
\hline 0801-02 & 710 & 1.02 & 0.37 \\
\hline 0801-03 & 875 & 1.26 & 0.67 \\
\hline 0901-01 & 1,500 & 2.52 & 1.45 \\
\hline \multicolumn{4}{|c|}{ 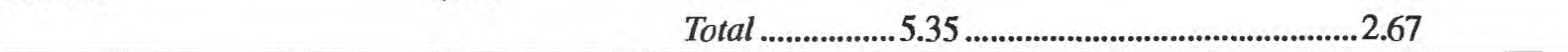 } \\
\hline \multicolumn{4}{|c|}{ South shore of eastern Molokai } \\
\hline 0449-01 & ${ }^{a} 1,000$ & 1.44 & 0.22 \\
\hline 0456-06 & a 75 & 0.11 & -- \\
\hline 0456-08 & $a_{75}$ & 0.11 & -- \\
\hline 0456-09 & a75 & 0.11 & -- \\
\hline 0457-01 & a 650 & 0.94 & 0.33 \\
\hline \multicolumn{4}{|c|}{ Total } \\
\hline
\end{tabular}

${ }^{a}$ Value is rated pump capacity.

b Value estimated from rated pump capacity and the number of hours pump was in use 


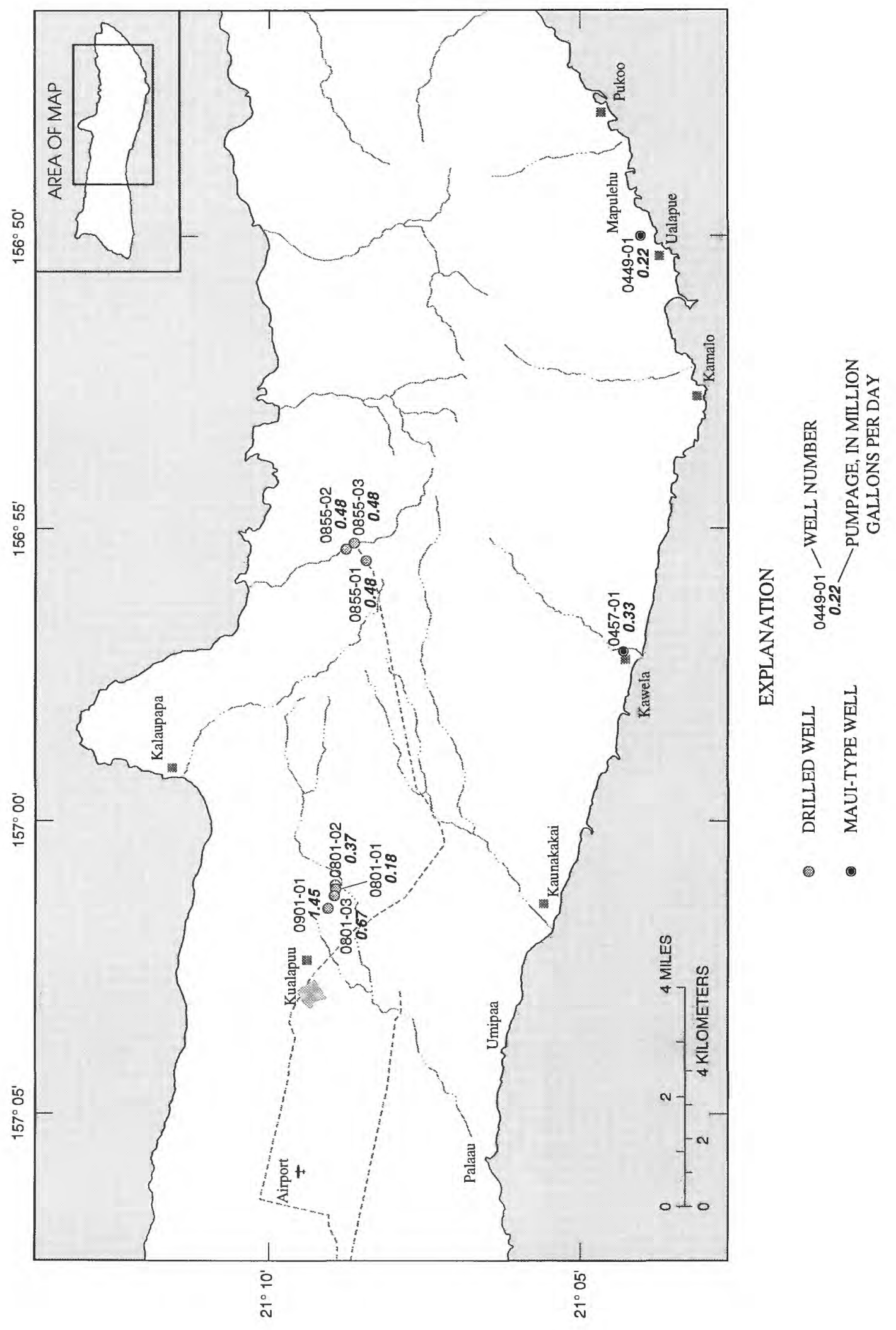

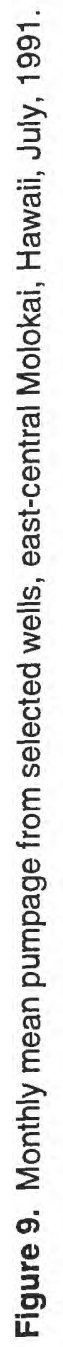


Most ground-water withdrawals along the south shore of eastern Molokai are from Kawela (0457-01) and Ualapue (0449-01) Maui-type wells. The annual mean pumpage for 1991 was $0.3 \mathrm{Mgal} / \mathrm{d}$ at Kawela Maui-type well, and $0.2 \mathrm{Mgal} / \mathrm{d}$ at Ualapue Maui-type well. Less than $0.1 \mathrm{Mgal} / \mathrm{d}$ of water is withdrawn from three drilled wells located just inland of Kawela Mauitype well. Pumpage records from these wells are not presently available. The seasonal demand for water is reflected in all of these records (fig. 10).

Combined pumpage from three production wells in Waikolu Valley averaged about 1.4 Mgal/d in July 1991 (table 3). The water from these wells is pumped into the Molokai Irrigation System and used to irrigate the fields on the Hoolehua Plain. Because pumpage from these wells is estimated from the rated pump capacity and an estimated number of hours the pump was in use, longterm records of monthly pumpage are not presented.

\section{Water Levels}

Water levels have been measured periodically at selected locations on eastern Molokai. The locations for which water levels are available are limited to the windward valley of Waikolu, an area east of Kualapuu, and along the south shore of eastern Molokai. The spatial and temporal distribution of water-level data is not sufficient to construct an accurate contour map of water levels for any period of time; however, a generalized distribution of water levels can be derived from periodic water-level measurements (fig. 11). Determination of water-level gradients and directions of ground-water flow is not possible from the water-level distribution shown on figure 11 , because the water-level measurements were made over a 54-year period (table 4).

The altitude and configuration of water levels are affected by the geometry of the system, the flux of ground water through the system, and the permeability of the rocks in the system. The range in water levels (from greater than $850 \mathrm{ft}$ above mean sea level in wells located in the windward valley of Waikolu to about 10 $\mathrm{ft}$ in wells located east of Kualapuu and $1 \mathrm{to} 5 \mathrm{ft}$ in the wells located along the south shore of eastern Molokai) indicates that dike-impounded water occurs near the crest of the mountains, and basal water occurs in the flanks of the East Molokai Volcano. Ground water impounded by dikes in the northwest rift zone flows through joints and gaps and over the top of dikes to the downgradient basal-water body before discharging to the sea.

The water-level gradient of the basal-water body between Kualapuu and Kaunakakai is about $2 \mathrm{ft} / \mathrm{mi}$ using water-level measurements from wells 0801-01 (10.7 ft), 0700-01 (6.1 ft), and 0601-01 (2.5 ft) (fig. 11 and table 4). An anomalously high water level of $8.9 \mathrm{ft}$ was reported in 1939 for well 0600-01 which is located in the bottom of Kaunakakai Gulch between Kualapuu and Kaunakakai at an altitude of $314 \mathrm{ft}$, and needs to be confirmed.

Along the south shore of eastern Molokai, water levels in the area between Umipaa and Kawela range from 1.1 to $2.5 \mathrm{ft}$ and from 3.8 to $5.0 \mathrm{ft}$ between Kamalo and Mapulehu (fig. 11). This difference in water levels may be due to one or more of the following factors: (1) a shorter ground-water flow path between the crest of the mountains and the area between Kamalo and Mapulehu, (2) a greater ground-water flux resulting from increased recharge between the crest of the mountains and the area between Kamalo and Mapulehu, and (3) a greater thickness of low-permeability deposits (caprock) that impede ground-water discharge in the area between Kamalo and Mapulehu compared with the area between Umipaa and Kawela.

Long-term records of water levels are available for seven wells (table 2), four of which are for observation wells. Available hydrographs include the seven longterm records and an additional four short-term (less than four years) records (fig. 12). The record for Ualapue Maui-type well (0449-01) extends over the longest period of time, from 1947 to present, but there is no record for the period 1964 to 1972 (fig. 12). The record for well 0601-01 represents the second-longest period of record, from 1954 to present (fig. 12).

Regardless of the period of record, when the hydrograph for one well is overlain on the hydrograph of another well for concurrent time periods, the trend in water levels among wells is consistent. In general, the hydrographs exhibit seasonal fluctuations on the order of $0.2 \mathrm{ft}$ resulting from seasonal changes in rainfall and pumpage and annual fluctuations up to $0.5 \mathrm{ft}$ resulting from changes in rainfall and pumpage. Long-term trends in water levels are not evident. 


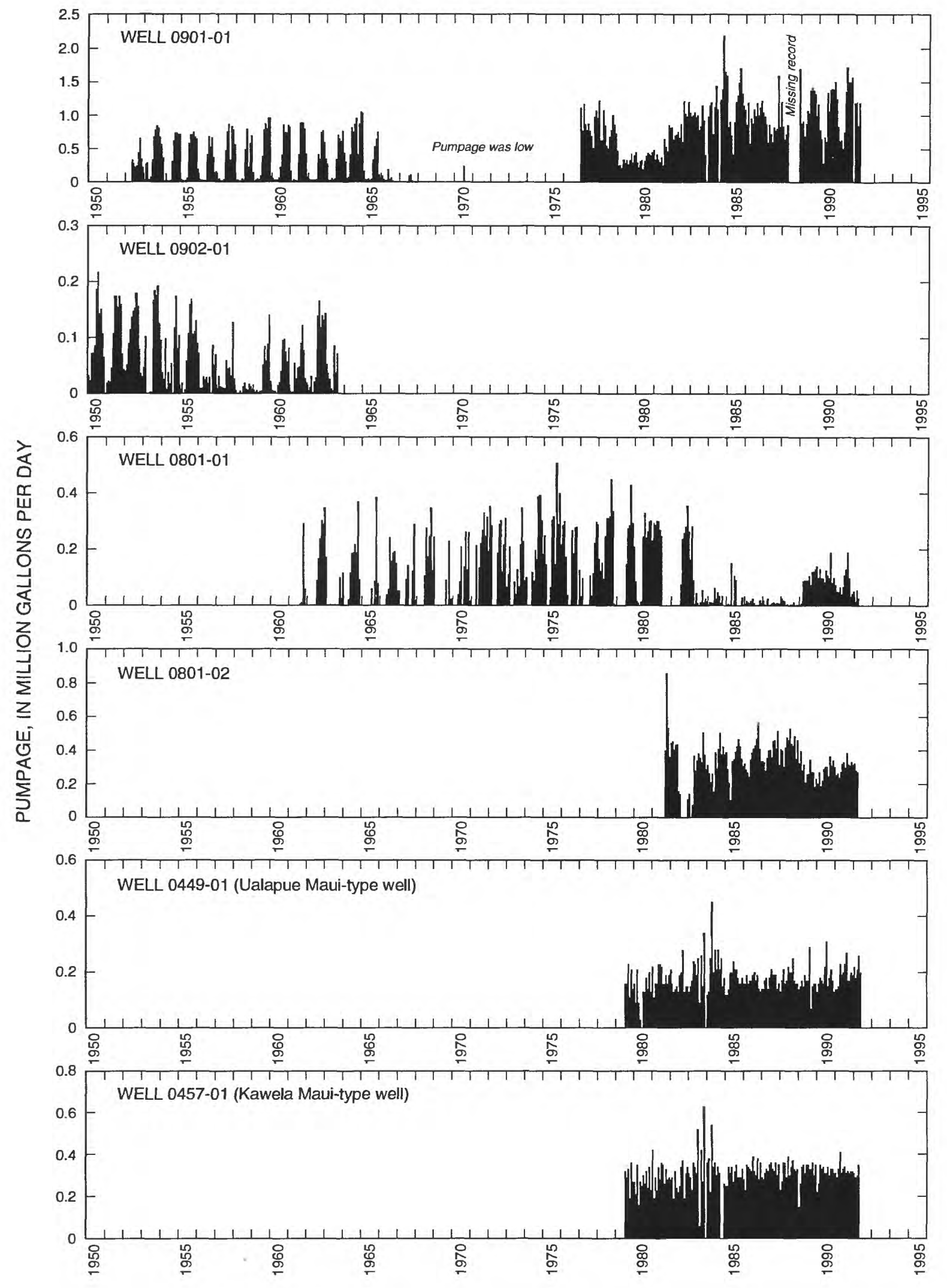

Figure 10. Monthly mean pumpage from selected wells, east-central Molokai, Hawaii. 


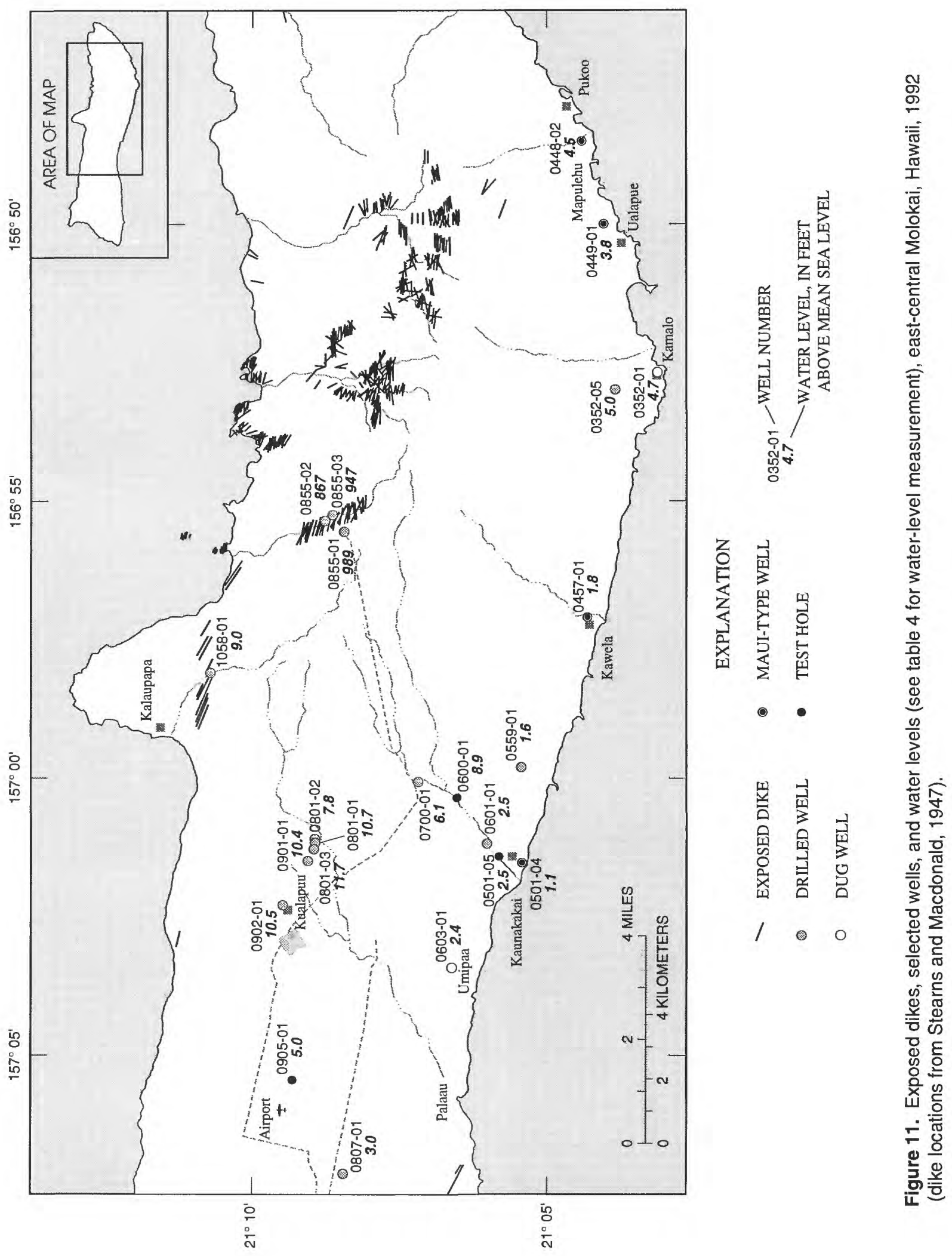


Table 4. Well characteristics and water-level data from wells in Waikolu Valley, Kualapuu area, and along the south shore of eastern Molokai, Hawaii

Local well number: $\mathrm{W}$ is drilled well

$$
\begin{aligned}
& \mathrm{T} \text { is test hole } \\
& \mathrm{D} \text { is dug well } \\
& \mathrm{S} \text { is shaft (Maui-type well) }
\end{aligned}
$$

\begin{tabular}{|c|c|c|c|c|c|c|}
\hline \multicolumn{2}{|c|}{ Well number } & \multicolumn{2}{|c|}{ Well characteristics } & \multirow[b]{2}{*}{$\begin{array}{l}\text { Water } \\
\text { level }\end{array}$} & \multirow[b]{2}{*}{$\begin{array}{c}\text { Date } \\
\text { measured }\end{array}$} & \multirow[b]{2}{*}{ Owner } \\
\hline State & Local & $\begin{array}{l}\text { Top of } \\
\text { casing }\end{array}$ & $\begin{array}{l}\text { Bottom of } \\
\text { hole }\end{array}$ & & & \\
\hline \multicolumn{7}{|c|}{ Waikolu Valley } \\
\hline 0855-01 & W22 & 992 & 592 & 989 & $06-29-61$ & Department of Agriculture \\
\hline 0855-02 & W23 & 904 & 604 & 864 & 04-03-61 & Department of Agriculture \\
\hline $0855-03$ & W23 & 965 & 665 & 947 & $07-10-61$ & Department of Agriculture \\
\hline \multicolumn{7}{|c|}{ Kualapuu area } \\
\hline $0700-01$ & W18 & 982 & -101 & 6.1 & $04-23-82$ & Kukui (Molokai), Inc. \\
\hline 0801-01 & W16 & 1,005 & -90 & 10.7 & $05-11-49$ & Department of Hawaiian Home Lands \\
\hline 0801-02 & W16B & 1,011 & -89 & 7.8 & $07-23-79$ & Department of Hawaiian Home Lands \\
\hline 0801-03 & none & 1,037 & -99 & 11.7 & $07-27-87$ & Maui County \\
\hline 0807-01 & none & 348 & -47 & 3.0 & $11-03-75$ & Kukui (Molokai), Inc. \\
\hline 0901-01 & W17 & 981 & -83 & 10.4 & $12-01-50$ & Kukui (Molokai), Inc. \\
\hline 0902-01 & W15 & 888 & -78 & 10.5 & $02-01-46$ & Kukui (Molokai), Inc. \\
\hline 0905-01 & $\mathrm{T} 1$ & 398 & -17 & 5.0 & $11-15-38$ & U.S. Geological Survey \\
\hline \multicolumn{7}{|c|}{ South shore of eastern Molokai } \\
\hline 0352-01 & D42 & 43 & 3 & 4.7 & $03-23-57$ & Maui County \\
\hline $0352-05$ & W31 & 213 & -27 & 5.0 & $11-27-61$ & Department of Land and Natural Resources \\
\hline 0448-02 & S8 & 21 & -2 & 4.5 & $10-21-91$ & Pearl Friel \\
\hline 0449-01 & S6 & 42 & -3 & 3.8 & 04-17-89 & Maui County \\
\hline 0457-01 & S4 & 37 & -2 & 1.8 & $04-26-90$ & Maui County \\
\hline 0501-04 & S1 & 28 & 1 & 1.1 & $05-15-43$ & Molokai Ranch \\
\hline $0501-05$ & $\mathrm{~T} 4$ & 16 & -6 & 2.5 & $11-12-53$ & Maui County \\
\hline 0559-01 & W19 & 273 & -14 & 1.6 & $07-03-62$ & Department of Land and Natural Resources \\
\hline 0600-01 & $\mathrm{T} 2$ & 314 & -10 & 8.9 & $09-27-39$ & Maui County \\
\hline 0601-01 & W11 & 52 & -8 & 2.5 & $09-08-86$ & Molokai Ranch \\
\hline 0603-01 & D14 & 18 & -1 & 2.4 & $01-29-75$ & Molokai Ranch \\
\hline
\end{tabular}

Well characteristics and water level: in feet relative to mean sea level 


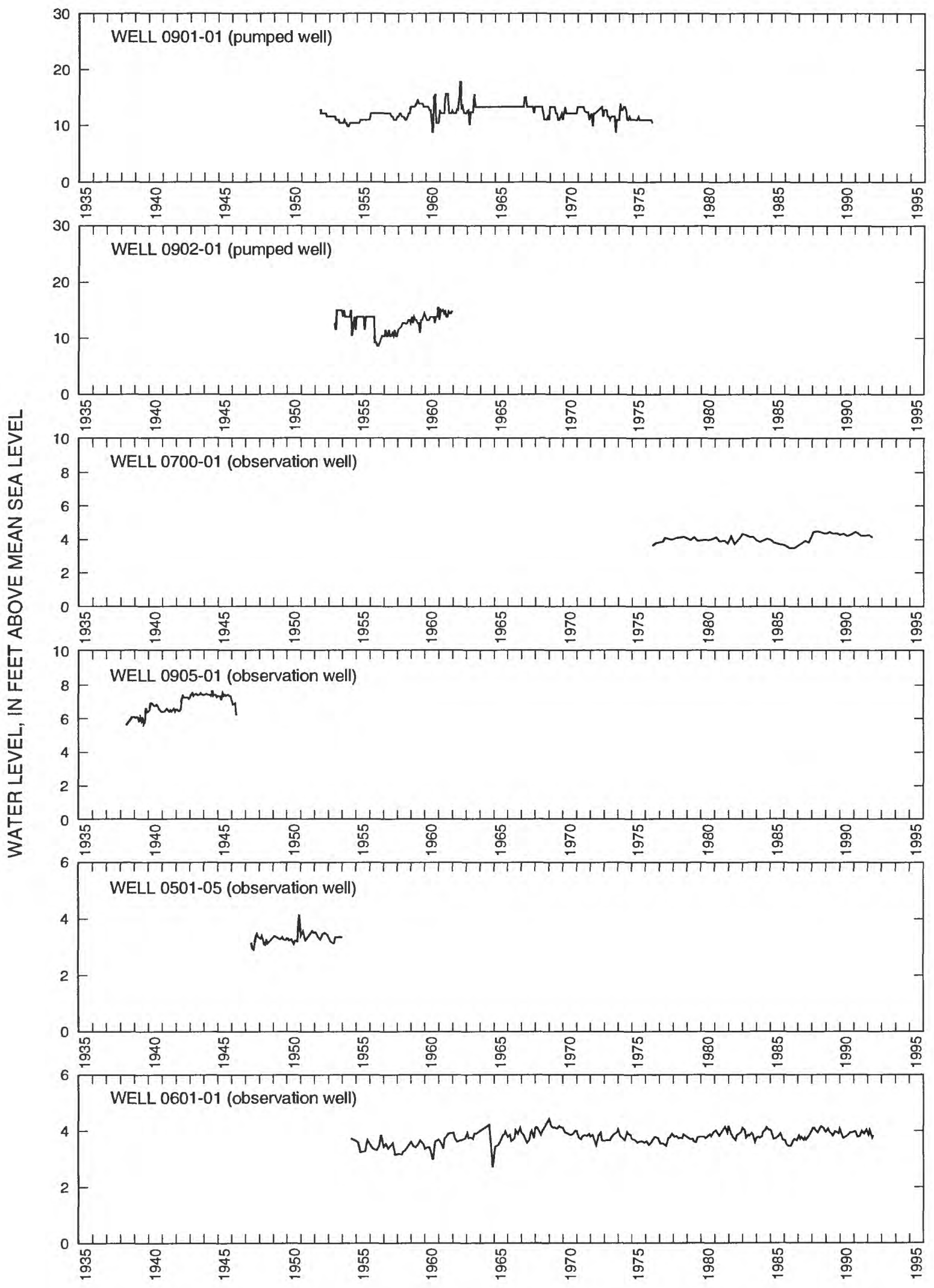

Figure 12. Monthly mean water levels from selected wells, east-central Molokai, Hawaii. 


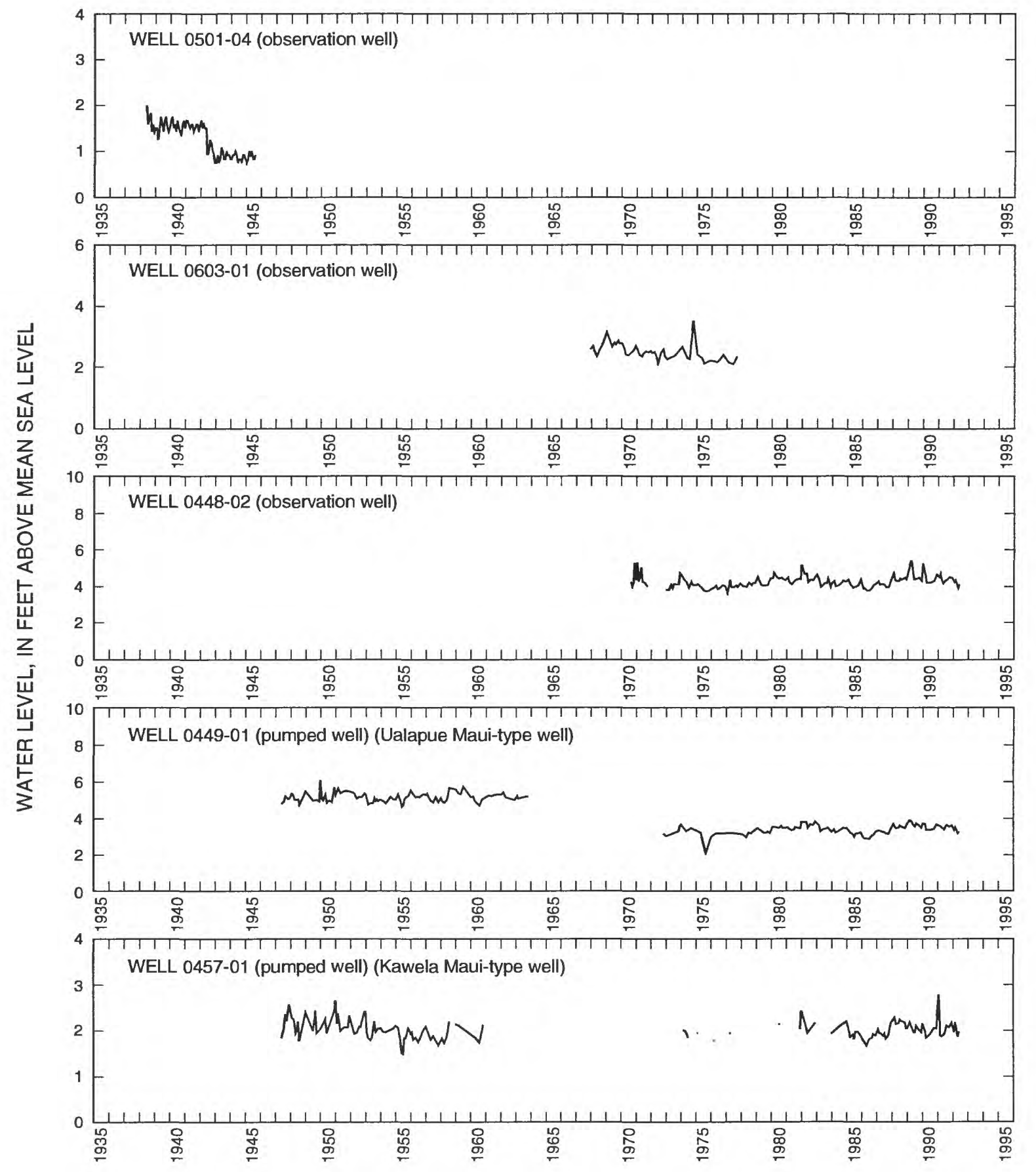

Figure 12. Monthly mean water levels from selected wells, east-central Molokai, Hawaii--Continued. 
The long-term water-level record in the Kualapuu area cannot be evaluated because the data are derived from inaccurate pressure measurements in an air-line. The hydrographs for pumped wells 0901-01 and 090201 are not reliable because the accuracy of measurements made by an air-line device varies with the accuracy of the pressure gages used and the care used in determining the initial pressure reading (fig. 12). The hydrograph for Ualapue Maui-type well (0449-01) shows a downward shift of about $2 \mathrm{ft}$ between the pre1963 data and the post-1972 data (fig. 12). This shift may be due to a surveying error. The water level in well 0601-01 has increased from the 2.0 to $2.5 \mathrm{ft}$ range to the 2.5 to $3.0 \mathrm{ft}$ range since 1961 (fig. 12). This increase may be due to the discontinued use of a nearby pumped well, the discharge of water from the west portal of the Molokai Irrigation tunnel into Kaunakakai Gulch, or both. Except for well 0700-01, the seasonal and annual variations in rainfall (fig. 5) are reflected in the waterlevel records (fig. 12).

\section{Chloride Concentrations}

The chloride concentration of water from wells in eastern Molokai has been determined periodically at selected locations. The spatial and temporal distribution of chloride data is not sufficient to construct an accurate contour map of chloride concentrations within the basal-water body for any period of time. Records are commonly incomplete because data are not collected at regular time intervals. None of the wells show a significant long-term increase in chloride concentration; however, variations due to the quantity of water pumped, and rainfall are evident. There also are no sites where information can be obtained on the variation in chloride concentration with depth through the freshwater part of the basal-water body and into the zone of transition between freshwater and saltwater.

Long-term records of chloride concentrations are available for 9 wells (table 2 and fig. 13). Evaluating chloride concentration trends from individual wells in the basal-water body is very difficult. Three of the longterm records are for wells that are not pumped (fig. 13); the other six records are for pumped wells with different rates of ground-water withdrawal and for which construction details, including well depth, are variable (fig. 13). The variation in chloride concentration of water pumped from an individual well commonly reflects changes in the rate at which water is withdrawn from the well. The variation also can reflect changes in rainfall and pumping rate.

Along the south shore of eastern Molokai, longterm records of chloride concentrations are available for two observation and two pumped wells. The observation wells are well 0603-01 near Umipaa and well 060101 near Kaunakakai. The water from well 0603-01 is brackish, with a variation in chloride concentration between 260 and $750 \mathrm{mg} / \mathrm{L}$ during the period 1967 to 1977 (fig. 13). Inland of Kaunakakai at well 0601-01 the average chloride concentration of water was $93 \mathrm{mg} / \mathrm{L}$ with a seasonal variation of about $100 \mathrm{mg} / \mathrm{L}$ during the period 1954 to 1966 (fig. 13). During the period 1966 to present the average chloride concentration of the water sampled decreased to $25 \mathrm{mg} / \mathrm{L}$ with a seasonal variation of about $20 \mathrm{mg} / \mathrm{L}$. The decrease in average and seasonal variation of chloride concentration may be due to one or more of the following factors: (1) a change in the depth from which water samples were collected in the $10 \mathrm{ft}$ water column, (2) the discontinued use of a nearby pumped well, (3) the periodic discharge of water from the west portal of the Molokai Irrigation tunnel into Kaunakakai Gulch since the early 1960's, and (4) changes in rainfall.

Pumped wells along the south shore of eastern Molokai with long-term records of chloride concentrations are located near Kawela and Ualapue. The chloride concentration of water pumped from Ualapue Maui-type well (0449-01), has varied between 50 and $66 \mathrm{mg} / \mathrm{L}$ during the period 1971 to 1985 ; however, after the severe drought of 1952-53 it reached a maximum of $171 \mathrm{mg} / \mathrm{L}$ in September 1954 (fig. 13). At Kawela Maui-type well (0457-01) the chloride concentration of water pumped has varied between 37 and $130 \mathrm{mg} / \mathrm{L}$ during the period 1971 to 1985 (fig. 13). The chloride concentration of water from Kawela Maui-type well indicates a greater seasonal variation than that from Ualapue Maui-type well (fig. 13).

Water from three wells in the Kualapuu area had higher chloride concentrations immediately after the wells were constructed or after being temporarily abandoned as compared with the chloride concentration of water obtained after sustained pumping (table 5). All of these wells are located at an altitude between 888 and $1,011 \mathrm{ft}$, and penetrate between 78 and $101 \mathrm{ft}$ below sea level. The chloride concentration of water pumped from well 0902-01 was $987 \mathrm{mg} / \mathrm{L}$ when the well was completed in 1946 (table 4). After 21 days of pumping at 


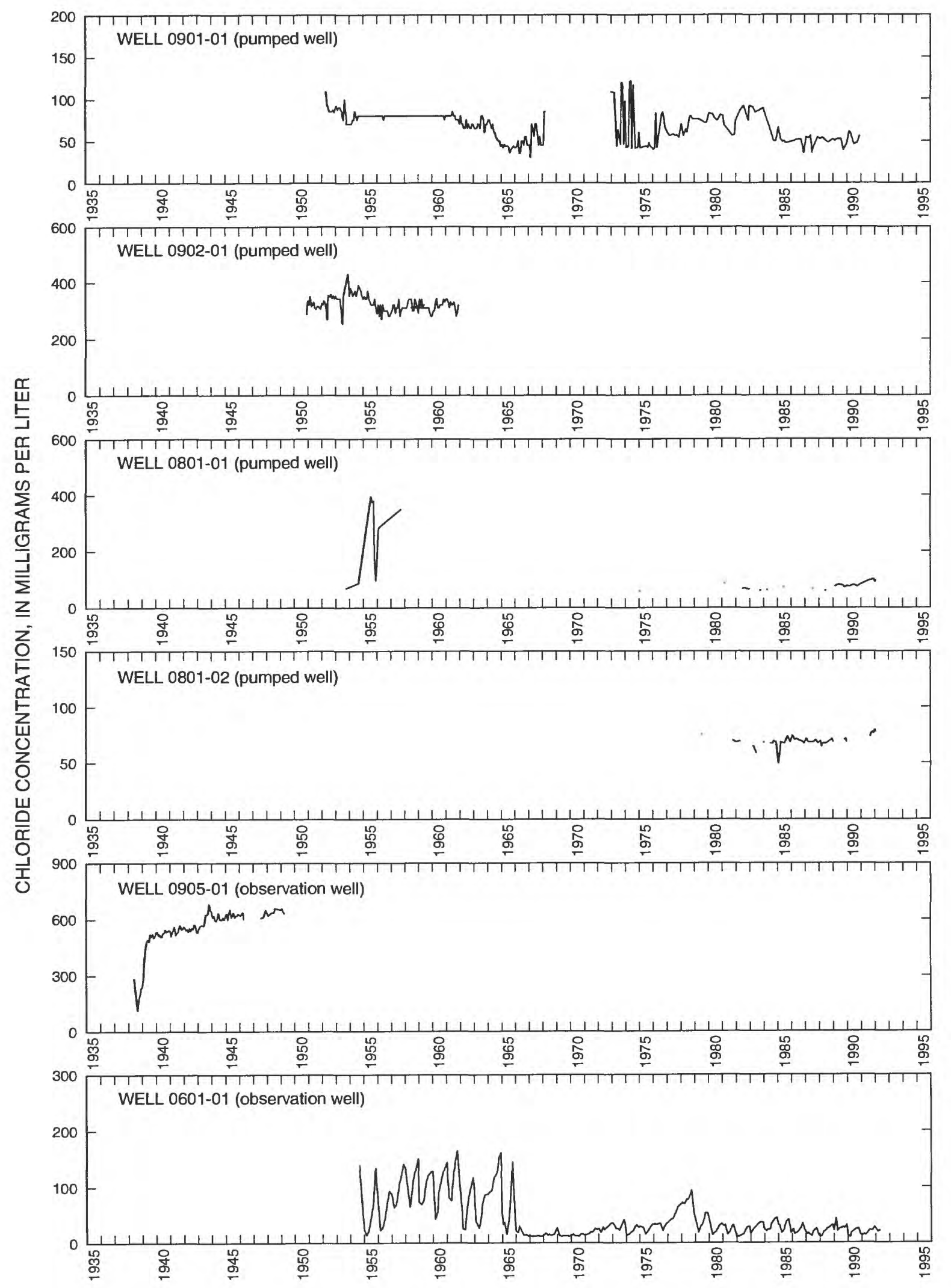

Figure 13. Monthly mean chloride concentrations from selected wells, east-central Molokai, Hawaii. 


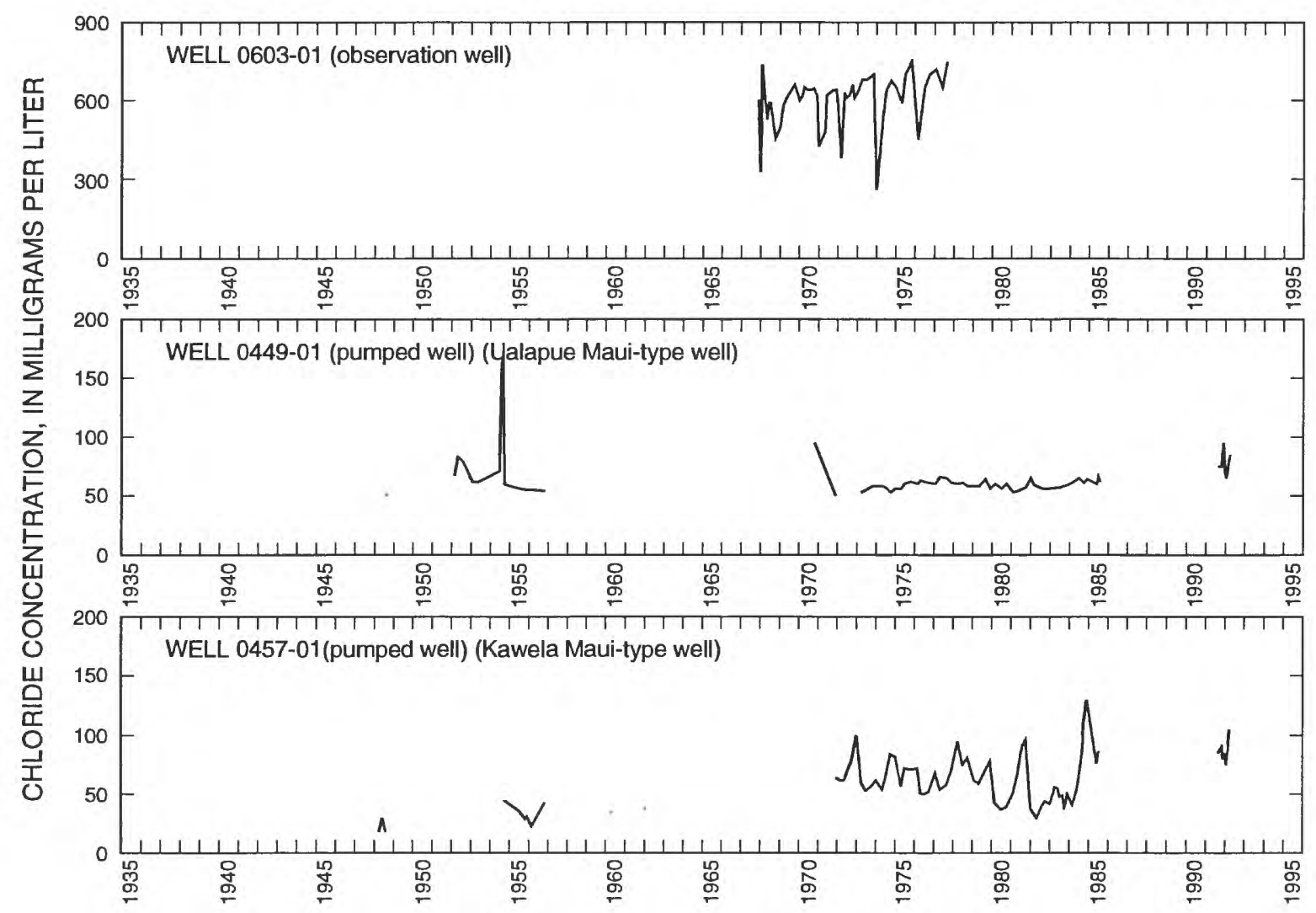

Figure 13. Monthly mean chloride concentrations from selected wells, east-central Molokai, Hawaii--Continued. 
Table 5. Pumping-test data from selected wells, Molokai, Hawaii

[gal/min, gallons per minute; (gal/min)/ft, gallons per minute per foot; $\mathrm{mg} / \mathrm{L}$, milligrams per liter; -- no data]

\begin{tabular}{|c|c|c|c|c|c|c|c|}
\hline \multirow[t]{2}{*}{ Well } & \multirow[t]{2}{*}{ Date } & \multirow{2}{*}{$\begin{array}{l}\text { Pumping rate } \\
\text { (gal/min) }\end{array}$} & \multirow{2}{*}{$\begin{array}{l}\text { Drawdown } \\
\text { (feet) }\end{array}$} & \multirow{2}{*}{$\begin{array}{l}\text { Specific capacity } \\
\text { (gal//min)/ft }\end{array}$} & \multicolumn{2}{|c|}{$\begin{array}{c}\text { Chloride } \\
\text { concentration } \\
(\mathrm{mg} / \mathrm{L})\end{array}$} & \multirow{2}{*}{$\begin{array}{l}\text { Duration } \\
\text { (hours) }\end{array}$} \\
\hline & & & & & begin & end & \\
\hline \multicolumn{8}{|c|}{ Variable-rate single-well pumping test } \\
\hline \multirow[t]{3}{*}{$0352-05$} & 1962 & ${ }^{\mathrm{a}} 400$ & ${ }^{\mathrm{a}} 0.46$ & 870 & 150 & ${ }^{\mathrm{a}} 128$ & 20 \\
\hline & & $a_{300}$ & ${ }^{\mathrm{a}} 0.25$ & 1,200 & 128 & ${ }^{\mathrm{a}} 152$ & 96 \\
\hline & & ${ }^{2} 250$ & -- & -- & 152 & ${ }^{\mathrm{a}} 157$ & 72 \\
\hline \multirow[t]{2}{*}{ 0449-01 } & 1962 & ${ }^{a} 300$ & ${ }^{\mathrm{a}} 0.15$ & 1,765 & 57 & $a_{57}$ & 12 \\
\hline & & ${ }^{\mathrm{a}} 100$ & ${ }^{\mathrm{a}} 0.06$ & 1,666 & 57 & a 57 & 12 \\
\hline \multirow[t]{3}{*}{ 0801-02 } & 1979 & a 800 & ${ }^{\mathrm{a}} 5.40$ & 148 & 72 & a75 & 28 \\
\hline & & 700 & a 4.25 & 165 & 70 & ${ }^{a} 72$ & 44 \\
\hline & & 350 & 1.20 & 292 & 70 & 70 & 1 \\
\hline \multirow[t]{5}{*}{ 0801-03 } & 1987 & ${ }^{a} 1,000$ & ${ }^{\mathrm{a}} 10.65$ & 93 & 70 & a68 & 88 \\
\hline & & a900 & ${ }^{\mathrm{a}} 6.20$ & 145 & 66 & ${ }^{a} 70$ & 2 \\
\hline & & ${ }^{\mathrm{a}} 700$ & ${ }^{a} 5.00$ & 140 & -- & - & 3 \\
\hline & & ${ }^{a} 600$ & ${ }^{a} 4.10$ & 146 & -- & - & 1 \\
\hline & & ${ }^{a} 500$ & 3.00 & 167 & - & -- & 2 \\
\hline \multirow[t]{5}{*}{$1058-01$} & 1983 & ${ }^{a} 455$ & ${ }^{\mathrm{a}} 15.0$ & 30 & -- & -- & 1 \\
\hline & & a395 & ${ }^{\mathrm{a}} 11.7$ & 34 & -- & -- & 2 \\
\hline & & ${ }^{a} 250$ & ${ }^{\mathrm{a}} 6.5$ & 39 & -- & -- & 2 \\
\hline & & ${ }^{\mathrm{a}} 156$ & $\mathrm{a}_{5} .0$ & 31 & 20 & ${ }^{a} 22$ & 40 \\
\hline & & ${ }^{a} 144$ & a 3.9 & 37 & -- & -- & 2 \\
\hline \multicolumn{8}{|c|}{ Constant-rate single-well pumping test } \\
\hline \multirow[t]{2}{*}{ 0457-01 } & 1946 & 820 & 0.67 & 1,220 & 30 & 310 & 720 \\
\hline & 1948 & 470 & - & -- & 20 & 58 & 720 \\
\hline 0559-01 & 1962 & ${ }^{a} 22$ & -- & - & 590 & ${ }^{a} 590$ & 22 \\
\hline 0600-01 & 1939 & 50 & 0.25 & 200 & -- & -- & 168 \\
\hline \multirow[t]{2}{*}{ 0700-01 } & 1969 & a 490 & 13.3 & 38 & 390 & ${ }^{\mathrm{a}} 445$ & 6 \\
\hline & 1974 & 800 & - & -- & 495 & 400 & 240 \\
\hline \multirow[t]{3}{*}{ 0801-01 } & 1949 & 413 & 2.50 & 165 & -- & 120 & 6 \\
\hline & 1956 & a340 & -- & - & 268 & ${ }^{2} 264$ & 4 \\
\hline & 1957 & 350 & -- & - & 375 & 320 & 3 \\
\hline 0807-01 & 1975 & 500 & 8.77 & 57 & 1,454 & 1,575 & 12 \\
\hline 0902-01 & 1946 & 200 & 5.0 & 40 & 987 & 375 & 505 \\
\hline
\end{tabular}

${ }^{a}$ Additional time-series data available 
$200 \mathrm{gal} / \mathrm{min}$ the chloride concentration decreased to $375 \mathrm{mg} / \mathrm{L}$ (table 5). Between 1950 and 1961 the chloride concentration of water pumped varied between 252 and $430 \mathrm{mg} / \mathrm{L}$ (fig. 13). The maximum chloride concentration of $430 \mathrm{mg} / \mathrm{L}$ occurred in December 1953 at the end of the severe drought of 1952-53.

During the drilling of well 0801-01 in 1948-49, the chloride concentration of water bailed from the well was $645 \mathrm{mg} / \mathrm{L}$ at $1,011 \mathrm{ft}, 302 \mathrm{mg} / \mathrm{L}$ at $1,040 \mathrm{ft}$, and 237 $\mathrm{mg} / \mathrm{L}$ at $1,055 \mathrm{ft}$. The well was completed at a depth of $1,095 \mathrm{ft}$, and after pumping for 2 hours the water had a chloride concentration of $120 \mathrm{mg} / \mathrm{L}$ (table 5). The chloride concentration of water from the well was less than $100 \mathrm{mg} / \mathrm{L}$ when the well was used during 1953-54 (fig. 13). The well was temporarily abandoned from 1955 to 1957 during which time a maximum chloride concentration of $394 \mathrm{mg} / \mathrm{L}$ was observed (fig. 13). During a 6hour pumping test at $350 \mathrm{gal} / \mathrm{min}$ in November 1957 , the chloride concentration of water pumped decreased from 375 to $320 \mathrm{mg} / \mathrm{L}$ (table 5). During the period 1975 to present, the chloride concentration of water pumped from the well has varied between 60 and $100 \mathrm{mg} / \mathrm{L}$ (fig. 13).

Well 0700-01 showed a decrease in chloride concentration from 495 to $400 \mathrm{mg} / \mathrm{L}$ after nine days of pumping at $800 \mathrm{gal} / \mathrm{min}$ in July 1974 (table 5). Bowles (1974) attributed the high chloride concentrations at the start of the test to a layer of high-salinity water in the top $60 \mathrm{ft}$ of the basal-water body. However, Lum (1981) and Nance (1982) showed that the chloride concentration of water in the well increases with depth, from 230 $\mathrm{mg} / \mathrm{L}$ at the top of the water column to $410 \mathrm{mg} / \mathrm{L}$ at the bottom of the water column on August 16, 1982 (Nance, 1982).

The higher chloride concentrations observed in wells 0801-01, 0902-01, and 0700-01 may result from a brackish layer of water atop the fresh basal-water lens. The origin of the brackish water may be salts from seaspray deposited on the soil and vegetation of the dry leeward slopes of eastern Molokai (fig. 14). The salts are then washed down to the water table by infiltrating rainfall. The chloride concentration of water pumped from these wells may have decreased during sustained pumping because of pumping-induced vertical movement of freshwater located below a layer of brackish water atop the fresh basal-water body.

Several of the wells in the Kualapuu area have not shown a significant decrease in chloride concentration after sustained pumping. The chloride concentration of water pumped from well 0901-01 was $114 \mathrm{mg} / \mathrm{L}$ when the well was completed in 1950. During the period 1952 to the present, the chloride concentration of water pumped has varied between 30 and $121 \mathrm{mg} / \mathrm{L}$ (fig. 13). The chloride concentration of water from well 0801-02 was $70 \mathrm{mg} / \mathrm{L}$ at the time the well was completed in 1979 and has varied from 50 to $80 \mathrm{mg} / \mathrm{L}$ from 1981 to present (fig. 13). The chloride concentration of water pumped from well 0801-03, which went into production in July 1991, has varied between 75 and $100 \mathrm{mg} / \mathrm{L}$.

\section{Hydraulic Information}

The only available hydraulic information (transmissivity and storage coefficient) for eastern Molokai is an analysis of a multiple-well aquifer test in Waikolu Valley (Williams and Soroos, 1973). Historically, the purpose of testing production wells was to establish a yield-drawdown relation in order to determine an acceptable pumping rate and depth of the pump intake; tests were seldom done to determine aquifer properties. Since about 1980, variable rate single-well (step-drawdown) pumping tests have become a routine testing procedure for most new production wells in the State of Hawaii. Multiple-well aquifer tests are still uncommon owing to the cost of constructing observation wells. Pumping-test data from selected wells are listed in table 5.

The aquifer test in Waikolu Valley was made on April 3-6, 1961. The aquifer is composed of lava flows and dikes of the lower member of the East Molokai Volcanics. The dikes divide the lava flows into more or less separate compartments and impound water to more than $850 \mathrm{ft}$ above sea level. Well 0855-02 was pumped at a rate of $1,005 \mathrm{gal} / \mathrm{min}$ for 68 hours, during which time water-level measurements were taken at the pumped well and at an observation well located $75 \mathrm{ft}$ away. The three methods used to analyze the drawdown data resulted in transmissivities of $2.0 \times 10^{4}$ to $3.2 \times 10^{4} \mathrm{ft}^{2} / \mathrm{d}$ and storage coefficients of $4.0 \times 10^{-3}$ to $5.0 \times 10^{-3}$ (Williams and Soroos, 1973). Because well 0855-02 partially penetrates the aquifer thickness, the transmissivity and storage coefficient values are considered to be underestimated. Boundaries located 617 and $1,310 \mathrm{ft}$ away from the pumped well were identified and presumed to be volcanic dikes (Williams and Soroos, 1973). 
占

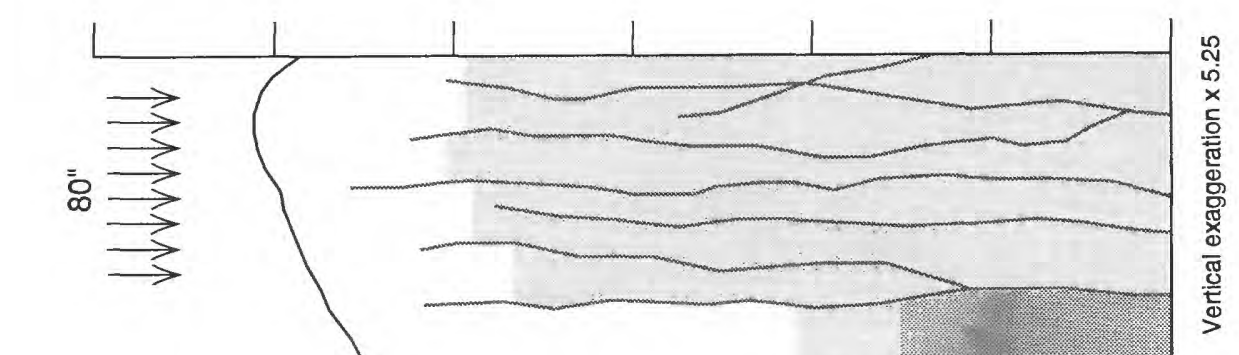

:

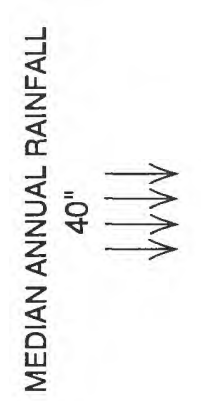

하

후 $\longrightarrow$

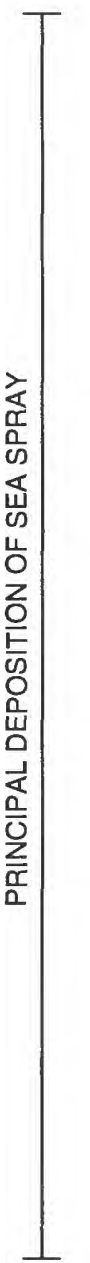

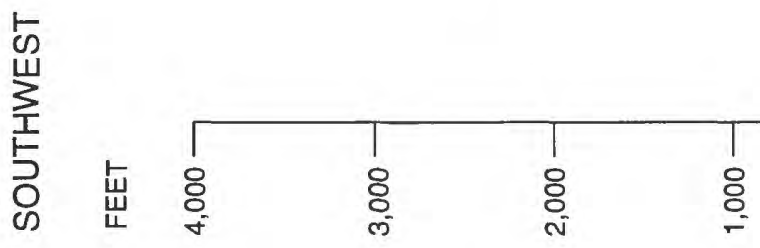




\section{NEED FOR ADDITIONAL DATA}

The evaluation of available ground-water data for the East Molokai Volcano indicates that additional data are needed in order to fully determine the availability of ground water. Additional observation wells located in areas of sparse data are needed to collect water-level, chloride, and aquifer-test data. The additional data, discussed below, could be used to develop and calibrate a numerical ground-water flow model to describe and manage the ground-water resources of the westem part of the East Molokai Volcano.

There are 120 registered wells on the island of Molokai; however, the spatial distribution of these wells is limited for the most part to a narrow strip along the south shore of eastern Molokai, an area east of Kualapuu, and Waikolu Valley. Only fourteen of the 120 registered wells have records of ground-water pumpage, water-level, or chloride data for a period of 10 years or more. Data from a network of observation wells distributed throughout the western part of the East Molokai Volcano are needed to construct an accurate contour map of water levels and chloride concentrations, and to determine the hydraulic properties and boundaries of the ground-water flow system. Contour maps of water levels and chloride concentrations are needed to determine ground-water flow directions and mixing processes.

To interpret trends in water-level and chloride data, water-level measurements and water samples need to be collected from observation wells rather than pumped wells. Data collected from pumped wells are ambiguous because of different rates of ground-water withdrawal and a lack of consistent construction details, including well depth. Data should be collected at regular time intervals, preferably monthly. The U.S. Geological Survey, in cooperation with the State Commission on Water Resource Management, presently collects waterlevel and/or chloride data at 6 to 8-week intervals from 9 wells on Molokai. There are only three observation wells in the program, none of which are equipped with a continuous ground-water level recorder. A continuous record of water levels would allow determination of barometric, tidal, and seasonal and long-term rainfall effects on ground-water levels.

Profiles of chloride concentration with depth through the freshwater part of the basal-water body and into the underlying transition zone are needed to deter- mine the chloride concentration distribution with depth and to evaluate the effect of ground-water withdrawals on the chloride concentration distribution in the basalwater body. To accomplish this, a deep monitoring well open below the water table could be located in the vicinity of the existing production wells to the east of Kualapuu. Deep monitoring wells also could be used to help determine the distribution and transport of salts in the Kualapuu area.

Finally, information from aquifer tests is needed to describe permeability of the rocks in the western part of the East Molokai Volcano. The use a of pumped well and one or more observation wells allows for the determination of transmissivity and storage coefficient values. Transmissivity values also can be obtained from pumping-well drawdown data if a variable (step-drawdown) and constant-rate test is made.

\section{SUMMARY}

Fresh ground water on Molokai is contained in the rocks of the East Molokai Volcano. The East Molokai Volcano is built largely of permeable basaltic lavas which erupted from a summit caldera and along east and northwest rift zones. Ground water in the East Molokai Volcano flows from the dike-impounded water bodies located in the rift zones near the crest of the mountains into streams, springs, and a basal-water body before discharging to sea. Recharge to the basal-water body occurs by direct infiltration of rainwater and by flow from upgradient dike-impounded water bodies.

Estimated ground-water withdrawals from Molokai averaged less than $5 \mathrm{Mgal} / \mathrm{d}$ during 1991. Most basal-water withdrawal is from four deep drilled wells at an altitude of about $1,000 \mathrm{ft}$ in an area east of Kualapuu, and from two Maui-type wells located at an altitude of less than $40 \mathrm{ft}$ along the south shore of the East Molokai Volcano. Dike-impounded water is withdrawn from three drilled wells in Waikolu Valley.

Long-term records of either ground-water pumpage, water-level data, or chloride data are available for only 14 of the 120 registered wells on the island of Molokai. Available water-level and chloride records are inadequate, because data were not collected at regular time intervals. Information is not presently available on the variation in chloride concentration with depth through the freshwater part of the basal-water body and 
into the zone of transition between freshwater and saltwater.

The altitude and configuration of water levels are governed by the geometry of the ground-water system, the flux of ground water through the system, and the permeability of the rocks in the system. The range in water levels from greater than $850 \mathrm{ft}$ in wells located in the windward valley of Waikolu to about $10 \mathrm{ft}$ in wells east of Kualapuu indicates that dike-impounded ground water occurs in the rift zone of East Molokai Volcano, whereas basal water occurs in the flanks of the volcano east of Kualapuu. Ground water impounded by volcanic dikes flows through joints and gaps and over the top of dikes to the downgradient basal-water body. The waterlevel gradient of the basal-water body between Kualap$\mathrm{uu}$ and Kaunakakai is about $2 \mathrm{ft} / \mathrm{mi}$ on the basis of water-level measurements from wells 0801-01 (10.7 ft), 0700-01 (6.1 ft), and 0601-01 (2.5 ft).

Along the south shore of eastern Molokai, water levels in the area between Umipaa and Kawela range from 1.1 to $2.5 \mathrm{ft}$ and between Kamalo and Mapulehu they range from 3.8 to $5.0 \mathrm{ft}$. This difference in water levels may be a result of one or more of the following factors: (1) a shorter ground-water flow path, (2) a greater ground-water flux, and (3) a greater thickness of low-permeability deposits (caprock).

Long-term records of chloride concentrations are available for ten wells. Six of the ten records are for wells with different pumping rates and construction details, including well depth. Water from three of the wells had higher chloride concentrations when the wells were constructed or temporarily abandoned as compared with the chloride concentrations measured after sustained pumping. The chloride concentration of water pumped from wells 0801-01 and 0902-01 decreased during sustained pumping probably as a result of pumping-induced vertical movement of freshwater located below a layer of brackish water atop the fresh basal-water body.

The only available hydraulic information is for an analysis of an aquifer test made in Waikolu Valley. A transmissivity of $2.0 \times 10^{4}$ to $3.2 \times 10^{4} \mathrm{ft}^{2} / \mathrm{d}$ and a storage coefficient of $4.0 \times 10^{-3}$ to $5.0 \times 10^{-3}$ was estimated for the lower member of the East Molokai Volcanics using three different methods (Williams and Soroos, 1973). These values are considered to be underestimated because the well is partially penetrating. Boundaries located 617 and 1,310 ft away from the pumped well were identified and presumed to be volcanic dikes (Williams and Soroos, 1973). Since about 1980, variablerate single-well (step-drawdown) pumping tests have become a routine testing procedure for most new production wells. Multiple-well aquifer tests are still rare owing to the cost of constructing observation wells.

The evaluation of available ground water data for the East Molokai Volcano indicates that additional data are needed in order to determine the availability of ground water. In most cases the need involves additional observation wells that would allow water-level, chloride, and aquifer-test data to be collected in areas of sparse data. The additional data could be used to develop and calibrate a numerical ground-water flow model to describe and manage the ground-water resources of the western part of the East Molokai Volcano.

Data from a network of observation wells distributed throughout the western part of the East Molokai Volcano are needed to construct contour maps of water levels and chloride concentrations, and to determine the hydraulic properties and boundaries of the ground-water flow system. Contour maps of water levels and chloride concentrations are needed to determine groundwater flow directions and mixing processes. Deep monitoring wells are needed to help determine the distribution and transport of salts in the Kualapuu area. Profiles of chloride concentration with depth through the freshwater part of the basal-water body and into the underlying transition zone are needed to determine the chloride-concentration distribution with depth and to evaluate the effect of ground-water withdrawals.

\section{SELECTED REFERENCES}

Austin, H.A.R., and Stearns, H.T., 1954, Methods for development and delivery of water for irrigation of Hawaiian Homes Commission Lands at Hoolehua Island of Molokai: Report to the Hawaii Irrigation Authority, Territory of Hawaii, $57 \mathrm{p}$.

Bowles, S.P., 1974, Salinity evaluation of the Kakalahale well no. 18, Molokai, Hawaii: Report prepared for Kalua Koi Corporation, 5 p.

Clague, D.A., Dao-Gong, C., Murnane, R., Beeson, M.H., Lanphere, M.A., Friesen, G.B., Holcomb, R.T., 1982, Age and petrology of the Kalaupapa basalt, Molokai, Hawaii: Pacific Science, v. 36, p. 411-420.

Division of Water and Land Development, 1962, Kaunakakai-Pukoo, A domestic water plan, Island of Molokai: Department of Land and Natural Resources, State of Ha- 
waii, Water Resources Report No. 3, 26 p.

Division of Water and Land Development, 1966, Water resources development, Molokai: Department of Land and Natural Resources, State of Hawaii, Bulletin B16, 69 p.

Division of Water and Land Development, 1982, Median rainfall State of Hawaii: Department of Land and Natural Resources, State of Hawaii, Circular C88, 44 p.

Division of Water and Land Development, 1991, Ground water index and summary: Division of Water Resource Management, Department of Land and Natural Resources, State of Hawaii, February 5, 1991, 91 p.

Ekern, P.R. and Chang, J.-H., 1985, Pan evaporation: State of Hawaii, 1894-1983: Department of Land and Natural Resources, State of Hawaii, Report R75, 171p.

Fukunaga \& Associates, Inc., 1989, Molokai integrated water system study: Prepared for the County of Maui, Department of Water Supply, 30 p.

Giambelluca, T.W., Nullet, M.A., and Schroeder, T.A., 1986, Rainfall Atlas of Hawaii: Division of Water and Land Development, Department of Land and Natural Resources, State of Hawaii, Report R76, 267 p.

Hirashima, G.T., 1963, Aspects of ground-water storage and depletion along the Molokai Irrigation Tunnel, Molokai, Hawaii: Division of Water and Land Development, Department of Land and Natural Resources, State of Hawaii, Circular C20, 21 p.

Holcomb, R.T., 1985, The caldera of East Molokai Volcano, Hawaiian Islands: National Geographic Society Research Reports, v. 21, p. 81-87.

Howell, H., 1938, Final report on water supply studies, Hawaii, F.P. No. 45, Island of Molokai; Description of project objectives, estimate of cost: U.S. Bureau of Reclamation, $111 \mathrm{p}$.

Hunt, C.D., Jr., Ewart, C.J., and Voss, C.I., 1988, Region 27, Hawaiian Islands: In Back, W., J.S. Rosenhein, and P.R. Seaber, eds., Hydrogeology: Boulder, Colorado, Geological Society of America, The Geology of North America v. 0-2, p. 255-262.

Langenheim, V.A.M., and Clague, D.A., 1987, The Hawaiian-Emperor volcanic chain, Part II: Stratigraphic framework of volcanic rocks of the Hawaiian Islands: chap. 1, of, U.S. Geological Survey, Professional Paper 1350, Volcanism in Hawaii, Volume 1, p. 55-84.

Lindgren, Waldemar, 1903, The water resources of Molokai, Hawaiian Islands: U.S. Geological Survey, Water-Supply and Irrigation Paper No. 77, 62 p.

Lum, Daniel, 1981, Kakalahale well 0700-01, Well logging survey, April 30, 1981, Molokai: Memorandum for the Record, Division of Water and Land Development, Department of Land and Natural Resources, State of Hawaii, 7 p.

M \& E Pacific, Inc., 1991, Water use and development plan for the island of Molokai 1992, Draft: Prepared for Department of Water Supply, County of Maui, $47 \mathrm{p}$.
Macdonald, G.A., Abbott, A.T., and Peterson, F.L., 1983, Volcanoes in the sea: University of Hawaii Press, Honolulu, Hawaii, 517 p.

MacCarthy, G.R., 1941, Geophysical studies on the island of Molokai, Territory of Hawaii: U.S. Department of the Interior, Geological Survey, Information Service, 2 p.

McDougall, Ian, 1964, Potassium-argon ages from the lavas of the Hawaiian Islands: Geological Society of America Bulletin, v. 75, p. 107-128.

Nance, Tom, 1982, Molokai Water Systems Plan: Prepared for the Maui County Department of Water Supply by Belt Collins \& Associates, 109 p.

Naughton, J.J., Macdonald, G.A., Greenburg, V.A., 1980, Some additional potassium-argon ages of Hawaiian rocks; the Maui volcanic complex of Molokai, Lanai, and Kahoolawe: Journal of Volcanology and Geothermal Research, v. 7, p. 339-355.

Parsons, Brinckerhoff, Hirota Associates, 1969, Island of Molokai, Waikolu and Pelekunu valleys, Water resources feasibility study: Department of Land and Natural Resources, State of Hawaii.

Stearns, H.T., 1946, Geology of the Hawaiian Islands: Bulletin 8, Division of Hydrography, Territory of Hawaii, 106 p.

State of Hawaii, 1982, Median rainfall: Department of Land and Natural Resources Circular 88, 44 p.

State of Hawaii, 1990, Water Resources Protection Plan, volumes I and II, Hawaii Water Plan: State of Hawaii,Commission on Water Resource Management.

Stearns, H.T., and Macdonald, G.A., 1947, Geology and ground-water resources of the island of Molokai, Hawaii: Bulletin 11, Division of Hydrography, Territory of Hawaii, 113 p.

Takasaki, K.J., and Mink J.F., 1985, Evaluation of major dike-impounded ground-water reservoirs, island of Oahu: U.S. Geological Survey Water-Supply Paper 2217,77 p.

Underwood, M.R., Meyer, William, and Souza, W.R., 1995, Ground-water availability from the Hawi aquifer in the Kohala area, Hawaii: U.S. Geological Survey Water-Resources Investigations Report 95-4113, 57 p.

Wentworth, C.K., 1945, Exploration for and development of water supplies for Kaunakakai: Letter to County of Maui, 4 p.

Williams, J.A., and Soroos, R.L., 1973, Evaluation of methods of pumping test analyses for application to Hawaiian aquifers: University of Hawaii, Water Resources Research Center, Tech. Report 70, 159 p. 